BIANNUAL WATER-RESOURCES REVIEW,

WHITE SANDS MISSILE RANGE, NEW MEXICO, 1986 AND 1987

By Robert G. Myers and Steven C. Sharp

U.S. GEOLOGICAL SURVEY

Open-File Report 89-49

Prepared in cooperation with

the U.S. DEPARTMENT OF THE ARMY,

WHITE SANDS MISSILE RANGE

Albuquerque, New Mexico 


\author{
DEPARTMENT OF THE INTERIOR \\ MANUEL LUJAN, JR., Secretary
}

U.S - GEOLOGICAL SURVEY

Dallas L. Peck, Director

For additional information

write to:

District Chief

U.S. Geological Survey

Pinetree office Park

4501 Indian School Road NE, Suite 200

Albuquerque, New Mexico 87110
Copies of this report can be purchased from:

U.S. Geological Survey Books and Open-File Reports Federal Center, Building 810 Box 25425

Denver, Colorado 80225 
Abstract......................................... 1

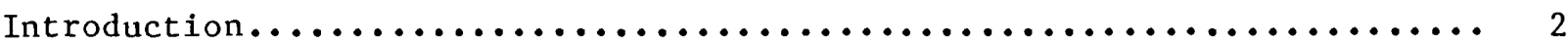

Well-numbering system................................. 3

Data-collection program.............................. 4

Ground-water pumpage.............................. 4

Water-level measurements in water-supply wells............... 4

Water-level measurements in test wells, observation we1ls, and

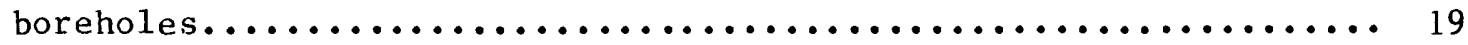

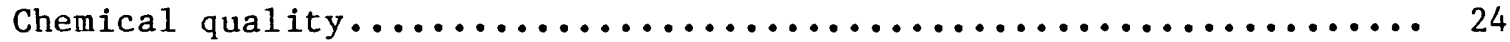

Selected references.................................... 36

\section{F IGURES}

Figure 1. Map showing location of White Sands Missile Range and areas of hydrologic observations............... 2

2. Diagram showing system of numbering wells in New Mexico... 3

3-7. Maps showing location of:

3. Water-supply we11s, test wells, boreholes, unused water-supply wells, and precipitation station in the Post Headquarters and adjacent areas.......... 5

4. Wells in the Mockingbird Gap area................ 6

5. Wells in the Stallion Range Center and NW-30 areas.... 6

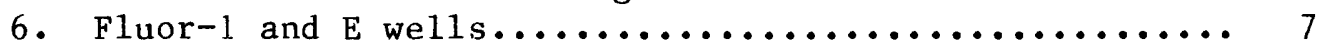

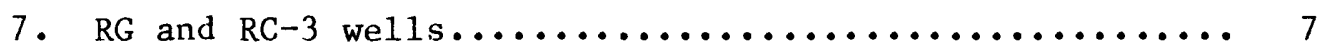

8-11. Hydrographs showing:

8. Water levels in test well $\mathrm{T}-8$ and yearly pumpage from the Post Headquarters wel1 field, 1971-87...... 13

9. Water levels and specific conductance for period of record available in selected water-supply

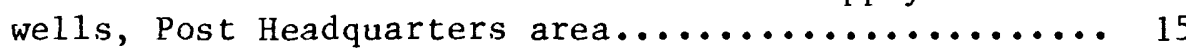

10. Water levels in test wells $\mathrm{T}-7, \mathrm{~T}-8, \mathrm{~T}-10$,

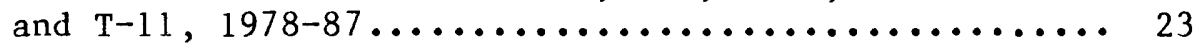

11. Monthly specific conductance and pumpage for Post Headquarters water-supply wells, 1986 and $1987 \ldots \ldots \ldots 27$ 
Table 1. Monthly precipitation, in inches, at White Sands Missile Range, 1986 and 1987 (22S.05E.36.224).................... 8

2. Monthly sewage influent, in gallons, for Post Headquarters,

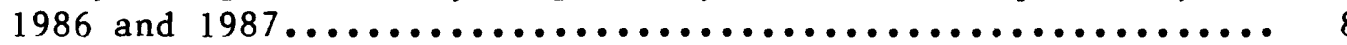

3. Total ground-water pumpage in water-supply wells, Post

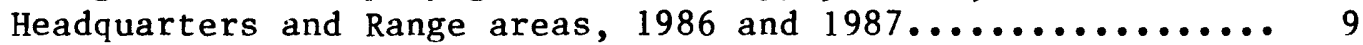

4. Depth to water in water-supply wells, Post Headquarters and Range areas, 1986 and $1987 \ldots \ldots \ldots \ldots \ldots \ldots \ldots \ldots \ldots \ldots \ldots \ldots$

5. Depth to water in test and observation wells, Post Headquarters and Range areas, 1986 and $1987 \ldots \ldots \ldots \ldots \ldots \ldots \ldots 20$

6. Depth to water in boreholes, Post Headquarters and

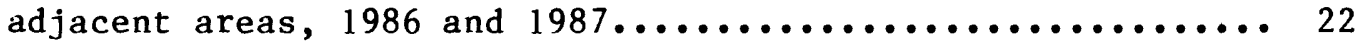

7. Chemical analyses of water from selected wells, 1986 and

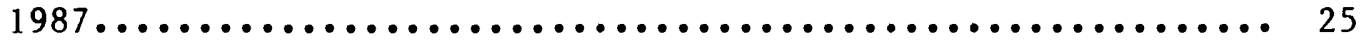

8. Volatile organic-compound analyses of water from selected

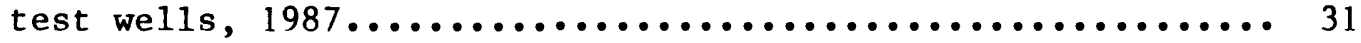

9. Specific conductance of water samples collected from test and water-supply wells in the Post Headquarters

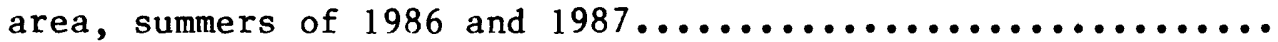

\section{CONVERSION FACTORS}

Measurements in this report are in inch-pound units. Use the following table to convert to metric units.

Multiply inch-pound units

inch

foot

mile

gallon

million gallons

acre

acre-foot
By

$$
25.40
$$

0.3048

1.609

3.785

3,785

4,047

1,233
To obtain metric units

millimeter

meter

kilometer

liter

cubic meter

square meter

cubic meter

Temperature in degrees Celsius $\left({ }^{\circ} \mathrm{C}\right)$ can be converted to degrees Fahrenheit $\left({ }^{\circ} \mathrm{F}\right)$ by the equation:

$$
{ }^{O} F=9 / 5\left({ }^{\circ} \mathrm{C}\right)+32
$$

Sea level: In this report "sea level" refers to the National Geodetic Vertical Datum of 1929 (NGVD of 1929)--a geodetic datum derived from a general adjustment of the first-order level nets of both the United States and Canada, formerly called "Sea Level Datum of 1929." 


\title{
BIANNUAL WATER-RESOURCES REVIEW, WHITE SANDS MISSILE RANGE, NEW MEXICO, 1986 and 1987
}

\author{
By Robert G. Myers and Steven C. Sharp
}

\begin{abstract}
Hydrologic data were collected at White Sands Missile Range in 1986 and 1987. The total ground-water withdrawal in 1986 was $565,462,500$ gallons and in 1987 it was $620,492,000$ gallons. The 11 water-supply we1ls in the Post Headquarters well field produced 534,026,000 gallons, or about 94 percent of the total in 1986, and $574,337,000$ gallons, or about 93 percent of the total in 1987. In 1986, the six Range area water-supply wells produced $31,436,500$ gallons, whereas in 1987 the wells produced 46,155,000 gallons. The total ground-water withdrawal was $110,971,300$ gallons less in 1986 than in 1985, but $55,029,500$ gallons more in 1987 than in 1986 .

Water samples from five Post Headquarters water-supply we11s were collected for chemical analysis in 1986. The greatest dissolved-sodium concentration was 39 milligrams per liter in the sample from water-supply we11 SW-13, and the greatest dissolved-chloride concentration was 27 milligrams per liter in the sample from water-supply well sw-20. The sample from watersupply well SW-11 had the greatest concentrations of dissolved calcium ( 85 milligrams per 1iter) and dissolved sulfate (140 milligrams per 1iter). Samples also were collected from water-supply we11 Murray-SW and test we11 F1uor-1.

In 1987, water samples were collected from four test wells in the Post Headquarters area for analysis of selected volatile organic compounds. Water from test well E-1 may have traces of dichlorobromomethane, chloroform, and toluene present. Water from test well E-2 may have traces of toluene present and water from test well E-4 may have traces of chloroform present.

Twenty-eight water samples from we11s were collected for analysis of specific conductance in 1986 and 1987. In 1986, the specific conductance ranged from 248 microsiemens per centimeter at 25 degrees Celsius in water from test well $\mathrm{T}-17$ to 1,920 microsiemens per centimeter at 25 degrees Celsius in water from test wel1 T-14. In 1987, the specific conductance ranged from 250 microsiemens per centimeter at 25 degrees Celsius in water from test we 11 T-17 to 1,650 microsiemens per centimeter at 25 degrees Celsius in water from test we11 T-14.
\end{abstract}




\section{INTRODUCTION}

This report presents water-resources data that were collected at White Sands Missile Range (fig. 1) during 1986 and 1987 by personnel of the U.S. Geological Survey and White Sands Missile Range. Ground-water pumpage, waterlevel measurements, chemical-quality, precipitation, and sewage-influent data summarized in this report were obtained as a result of the continuing waterresources hydrologic-data-collection program sponsored by the Directorate of Engineering, Housing, and Logistics, White Sands Missile Range.

This report is the 19 th water-resources review prepared for the White Sands Missile Range. The 1968 report and subsequent reports are available for inspection at the District office of the U.S. Geological Survey, Water Resources Division, Albuquerque, New Mexico.

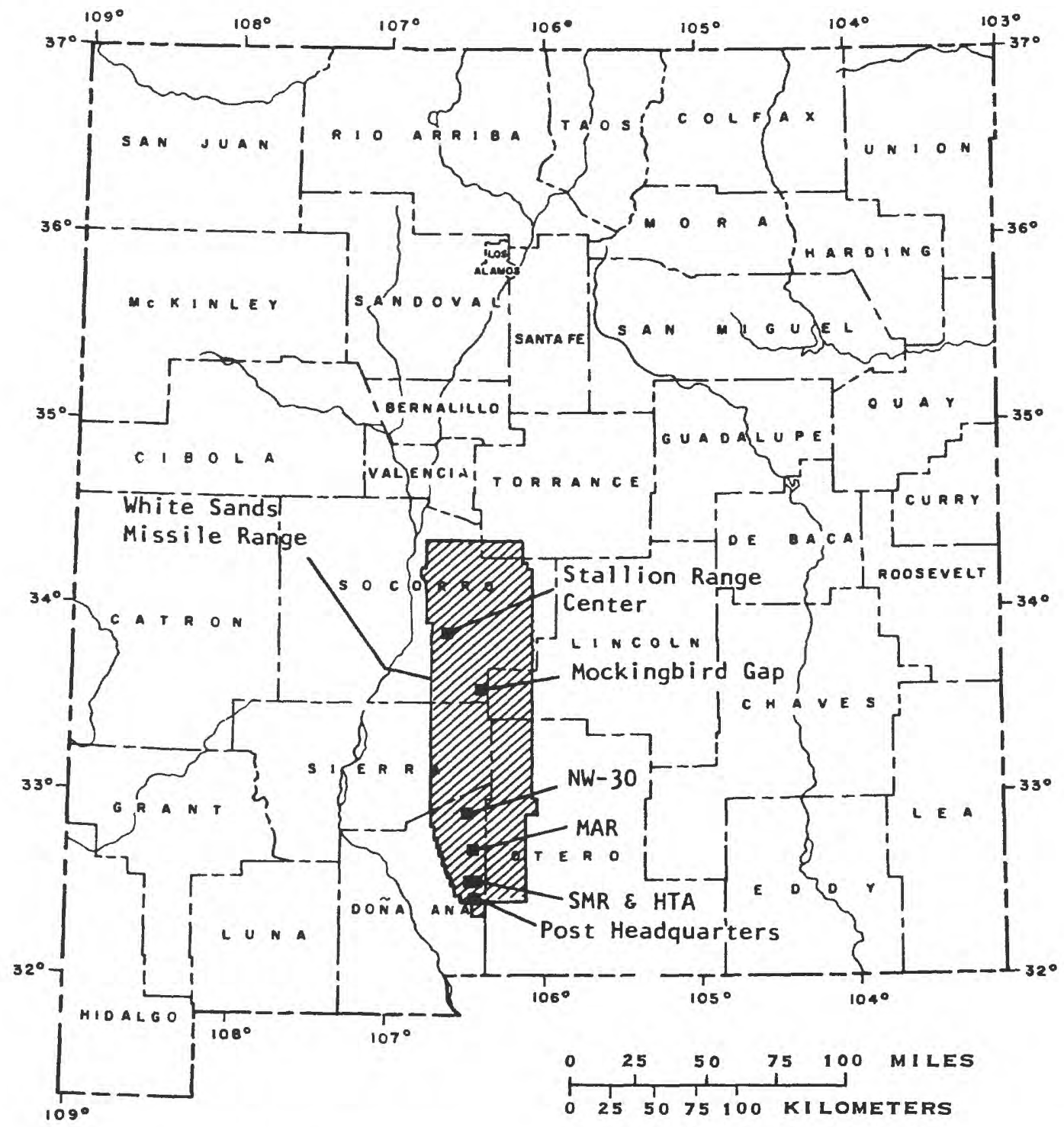

Figure 1.--White Sands Missile Range and areas of hydrologic observations. 


\section{WELL-NUMBERING SYSTEM}

We1ls are located according to the system of common subdivision of sectionized land used throughout the State by the U.S. Geological Survey (fig. 2). The number of each well consists of four segments separated by periods and locates the well's position to the nearest 10-acre tract of land. The segments denote, respectively, the township south of the New Mexico base line, the range east of the New Mexico principal meridian, the section, and the particular 10-acre tract within the section.

The fourth segment of the number consists of three digits denoting, respectively, the quarter section or approximate 160-acre tract, the quadrant (approximately 40 acres in size) of the quarter section, and the quadrant (approximately 10 acres in size) of the 40-acre tract in which the we 11 is located. The system of numbering quarter sections and quadrants, which is done in reading order, as well as the usual numbering of sections within a township is shown below. For example, well 22S.4E.1.431 is located in the NW1/4 of the SW1/4 of the SEl/4, section 1, Township 22 South, Range 4 East. If more than one well has the same location number, the letter " $a$ " is assigned to the second well, the letter "b" to the third well, and so on.

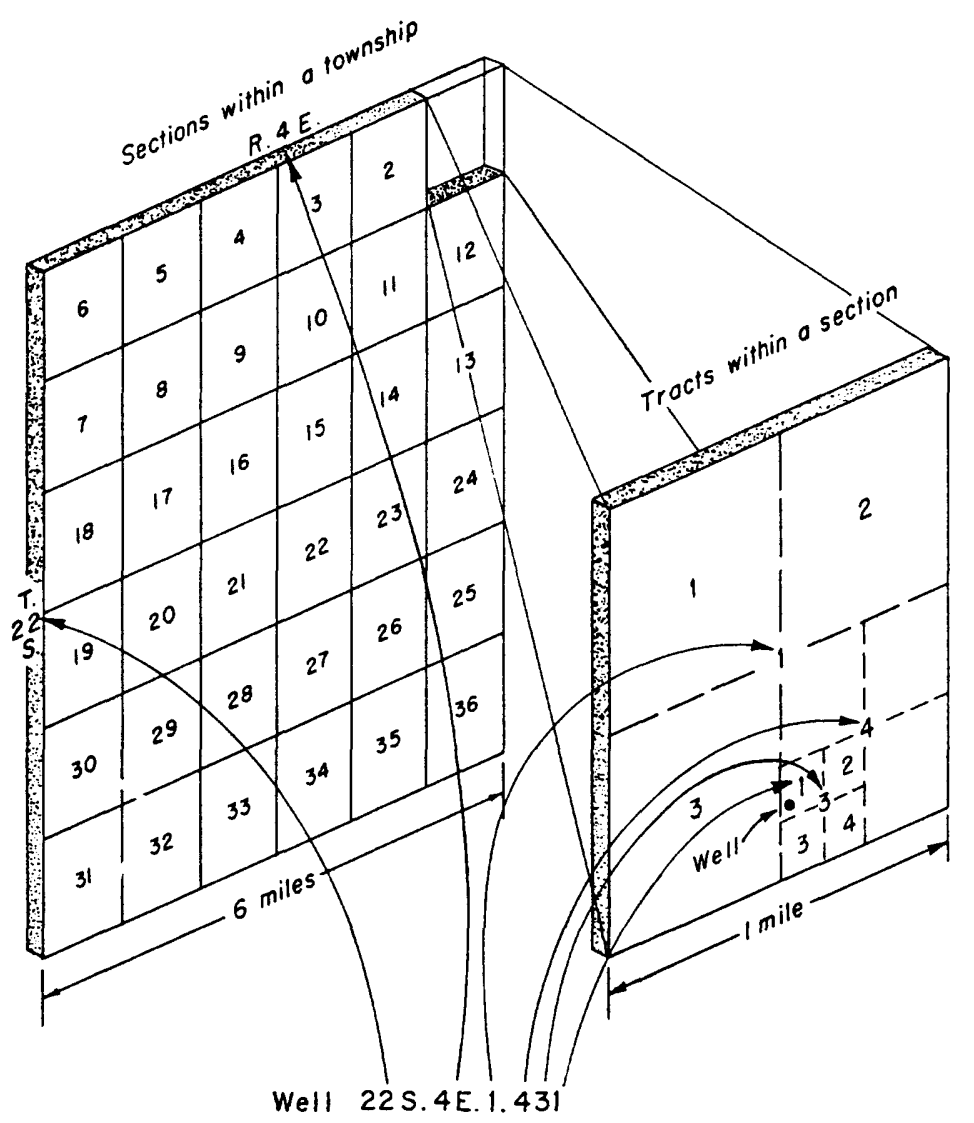

Figure 2.--System of numbering wells in New Mexico. 


\section{DATA-COLLECTION PROGRAM}

The program to collect hydrologic data at White Sands Missile Range has been continuous since 1953. The original program consisted of water-level measurements in five wells in the Post Headquarters area. The hydrologicdata-collection program has expanded over the years to keep up with expansion of the White Sands Missile Range facilities (fig. 1). Currently, the program consists of depth-to-water measurements in 97 wells, chemical analyses of water samples from 11 wells, and measurement of ground-water withdrawals from 17 wells in the Post Headquarters and Range areas (figs. 3-7). Precipitation data (22S.05E.36.224) and Post Headquarters sewage-influent data for 1986 and 1987 are shown in tables 1 and 2, respectively.

\section{Ground-Water Pumpage}

Total ground-water pumpage at White Sands Missile Range in 1986 was 565,462,500 gallons, and in 1987 pumpage was 620,492,000 gallons ( table 3). The Multifunction Array Radar wells (MAR-1 and MAR-2), Small Missile Range wells (SMR-1), Hazardous Test Area well (HTA-1), and the Stallion Range Center wells (SRC-1 and SRC-2) produced 6 percent of the total pumpage, or about $31,436,500$ gallons, in 1986, and 7 percent, or about 46,155,000 gallons, in 1987. The Post Headquarters well field produced 534,026,000 gallons in 1986 and 574,337,000 gallons in 1987. Water levels in test we11 T-8 from 1971 to 1987 and yearly pumpage from the Post Headquarters well field are shown in figure 8. Total ground-water pumpage was $110,971,300$ gallons less in 1986 than in 1985, but 55,029,500 gallons more in 1987 than in 1986 .

\section{Water-Level Measurements in Water-Supp1y We11s}

In 1986 and 1987, depth-to-water measurements were made in 10 we11s in the Post Headquarters area and 6 wells in the Range area (table 4 ). The greatest seasonal water-level fluctuation in 1986 was about 15 feet in watersupply well SRC-2. The greatest seasonal water-level fluctuation in 1987 was about 17 feet in water-supp1y well SW-17. Water-1evel measurements were not made in Post Headquarters water-supply well SW-15A because the air 1ine is inoperative and pumping equipment prohibits steel tape measurements. Hydrographs for 10 water-supply wells in the Post Headquarters area and specific conductance for period of record are shown in figure 9. Both seasonal fluctuations and long-term changes in water levels are shown in these hydrographs. 


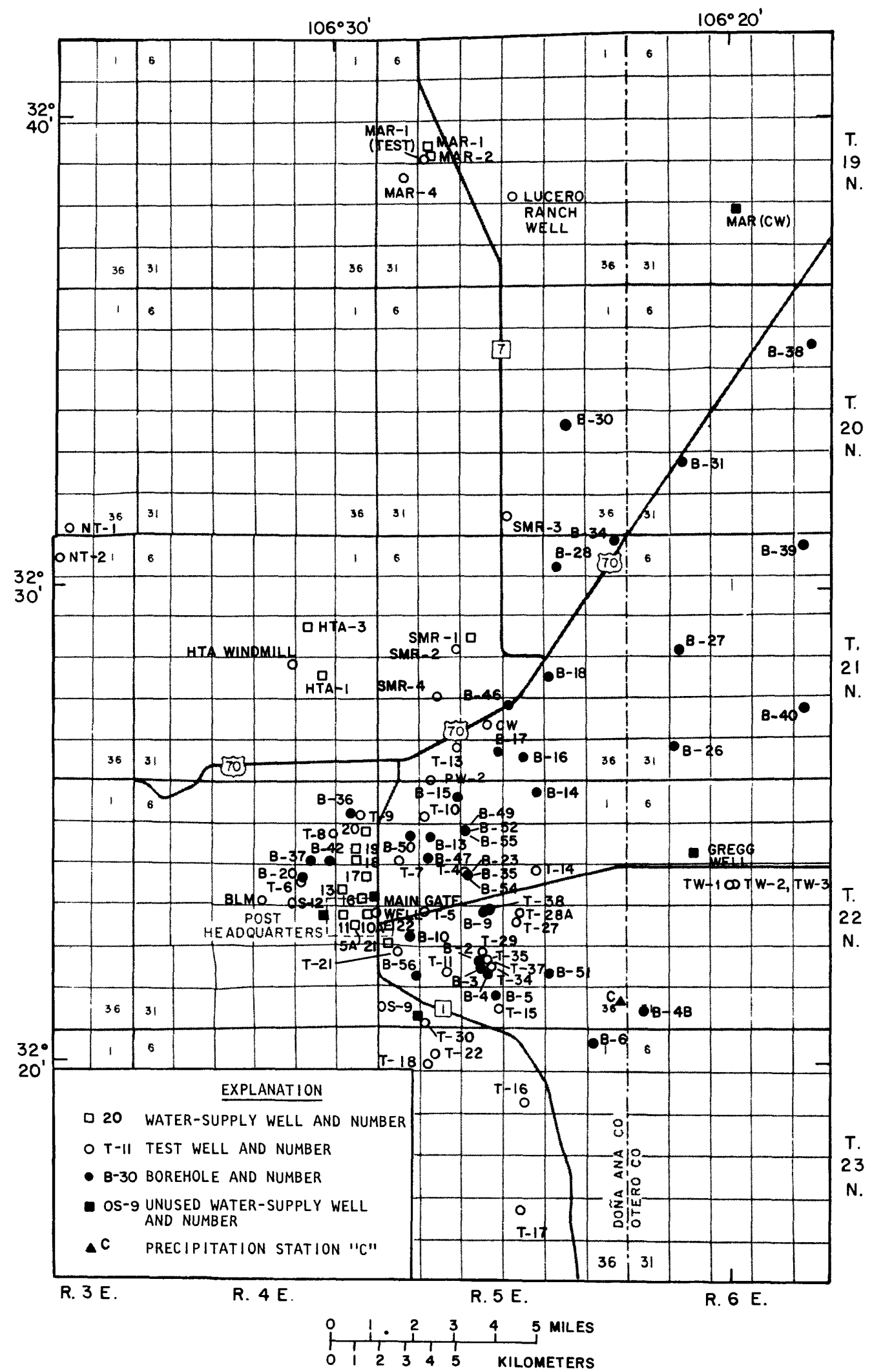

T.
9
N.

T.

21

N.

T. N.

Figure 3.--Location of water-supply wells, test wells, boreholes, unused water-supply sells, and precipitation station in the Post Headquarters and adjacent areas. 


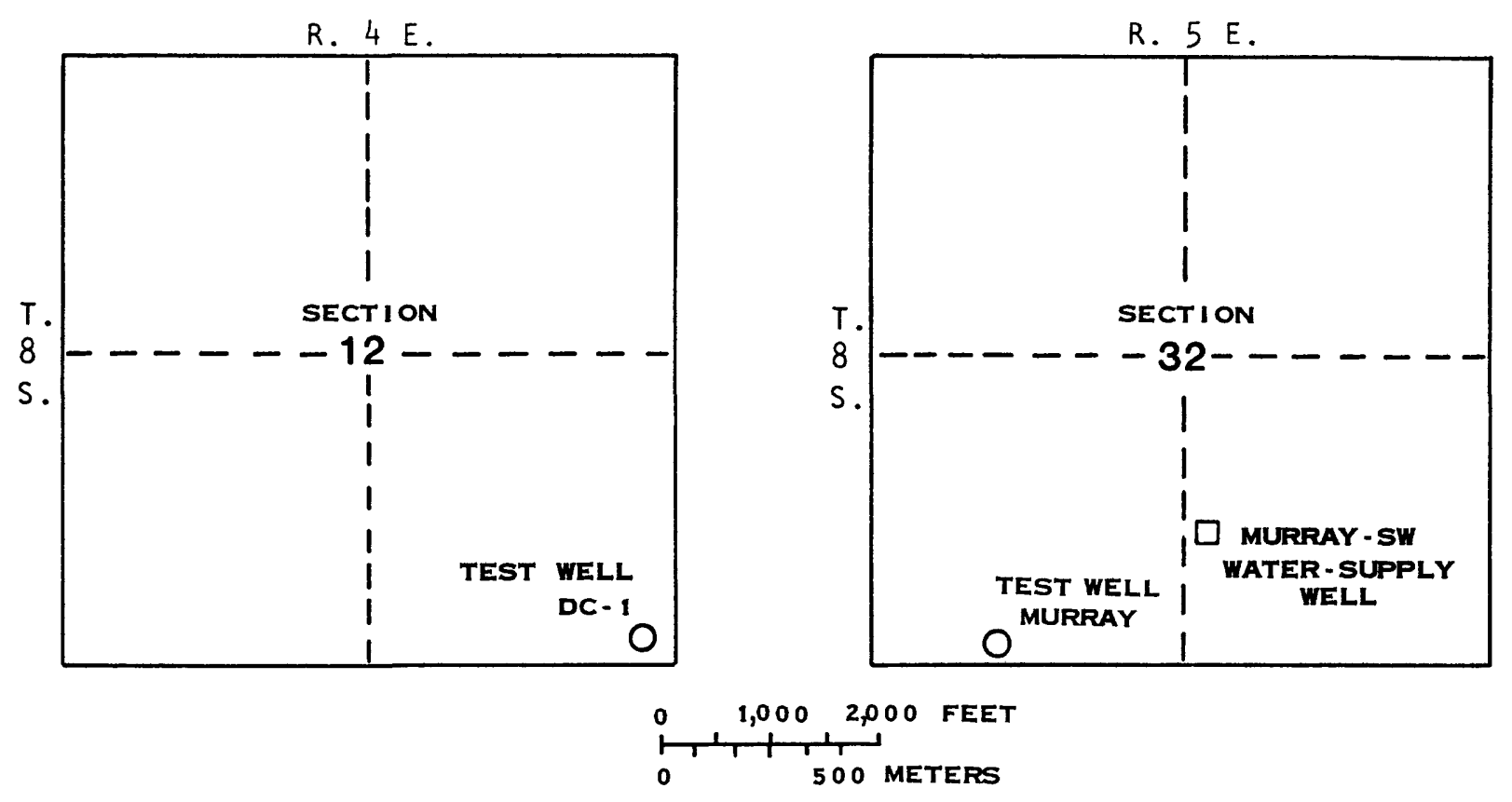

Figure 4.--Location of wells in the Mockingbird Gap area.

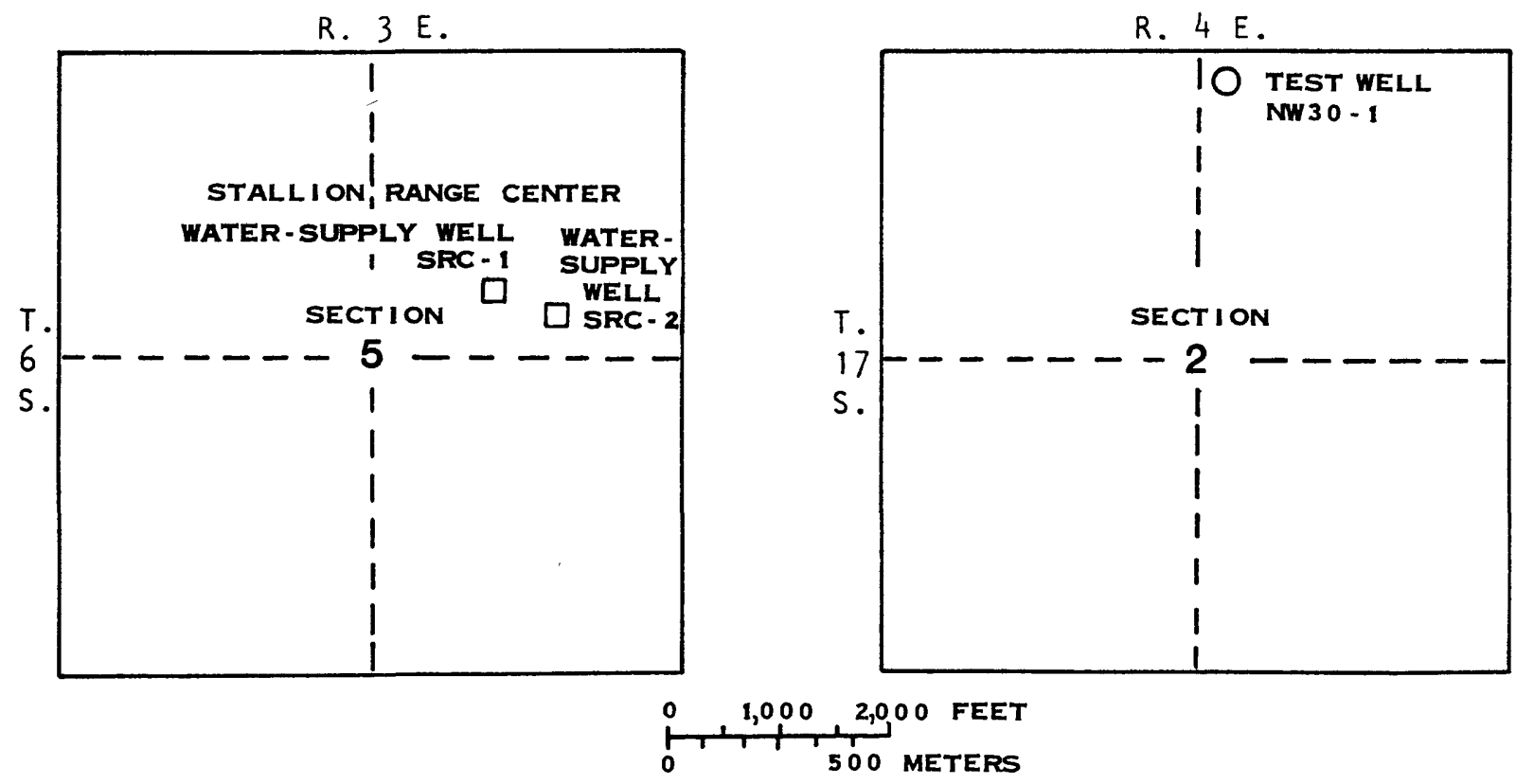

Figure 5.--Location of wells in the Stallion Range Center and NW-30 areas. 


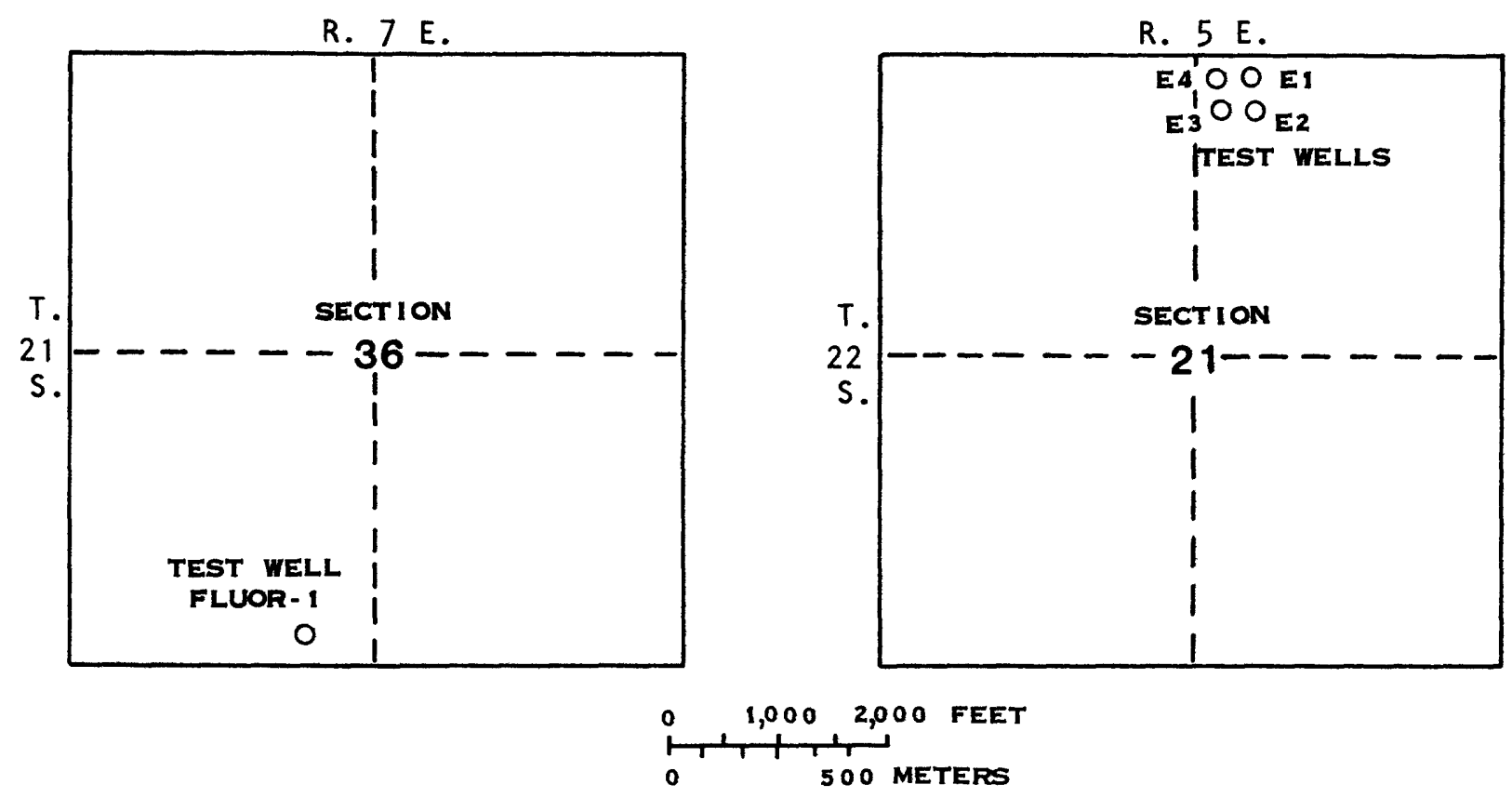

Figure 6.--Location of Fluor -1 and $E$ wells.

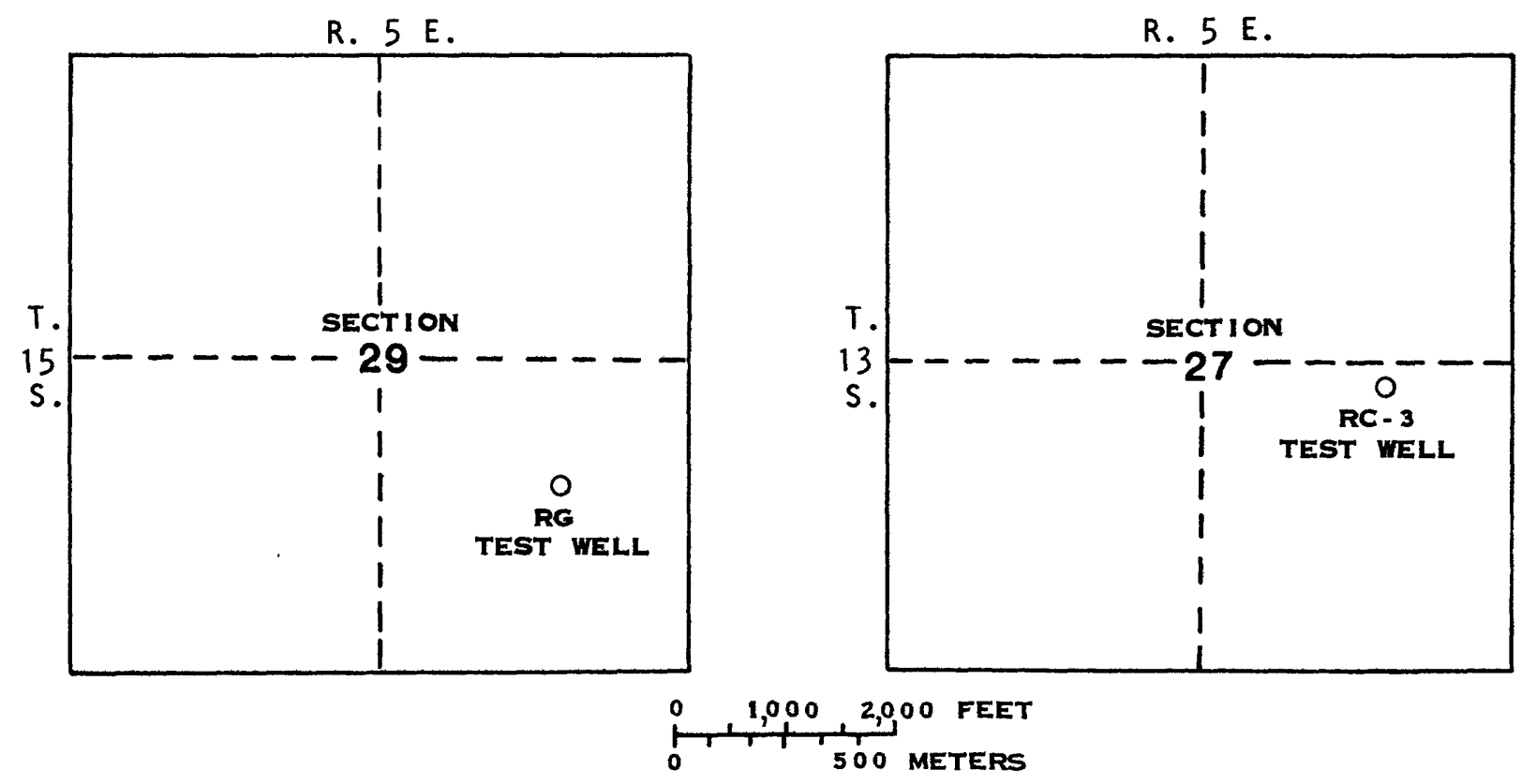

Figure 7.--Location of RG and RC-3 wells. 
Table 1.- Monthly precipitation, in inches, at White Sands Missile Range, 1986 and 1987 (22S.05E.36.224)

\begin{tabular}{lrr}
\hline Month & 1986 & 1987 \\
\hline January & 0.08 & 0.49 \\
February & .41 & .77 \\
March & .52 & .54 \\
April & Trace & .63 \\
May & .53 & .72 \\
June & 3.36 & 1.39 \\
July & 1.58 & .40 \\
August & 3.02 & .82 \\
September & 1.26 & .75 \\
October & 1.30 & .13 \\
November & 2.74 & .58 \\
December & 2.10 & 3.17 \\
\hline Totals & 16.90 & 14.39 \\
\hline
\end{tabular}

Table 2.--Monthly sewage influent, in gallons, for Post Headquarters, 1986 and 1987

\begin{tabular}{lcc}
\hline Month & 1986 & 1987 \\
\hline January & $16,116,600$ & $15,221,500$ \\
February & $14,159,800$ & $14,400,300$ \\
March & $16,031,800$ & $17,386,500$ \\
April & $15,807,500$ & $17,165,500$ \\
May & $17,359,900$ & $17,726,500$ \\
June & $16,671,100$ & $17,330,000$ \\
July & $16,978,000$ & $18,346,200$ \\
August & $17,963,500$ & $18,712,300$ \\
September & $17,644,000$ & $18,503,300$ \\
October & $17,660,000$ & $18,678,900$ \\
November & $15,630,000$ & $17,515,200$ \\
December & $15,940,700$ & $17,122,100$ \\
\hline Totals & $197,962,900$ & $208,108,300$ \\
\hline
\end{tabular}




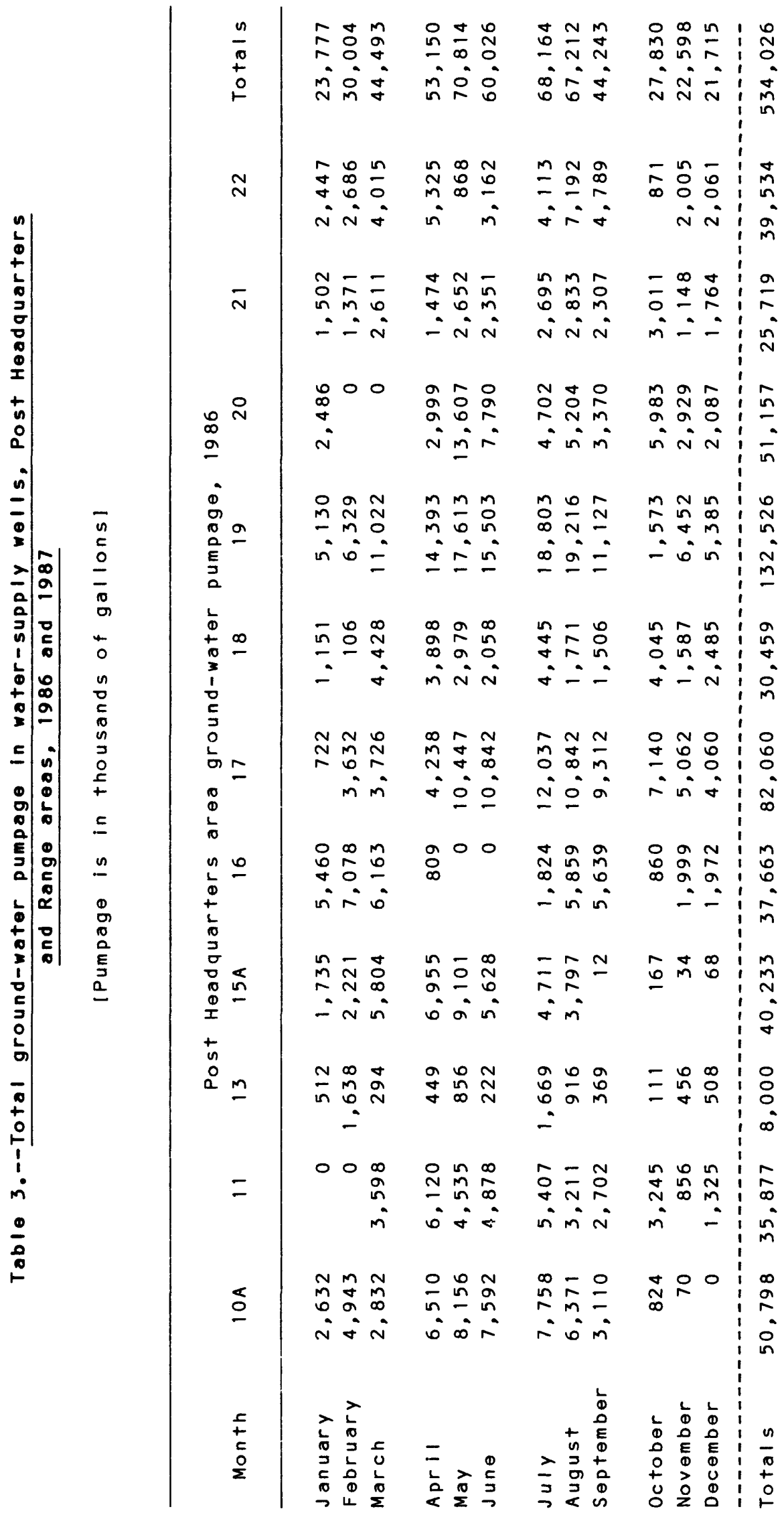




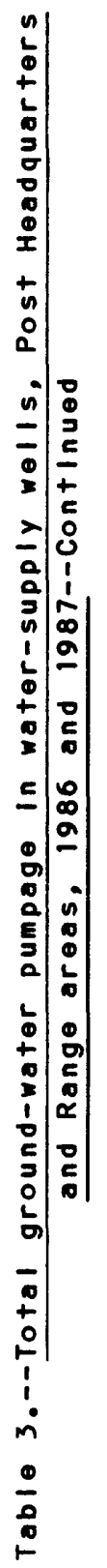

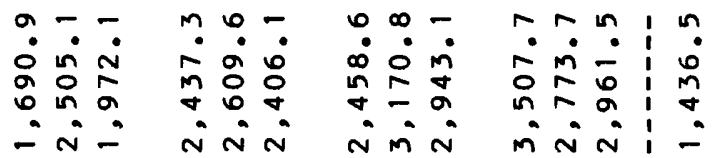

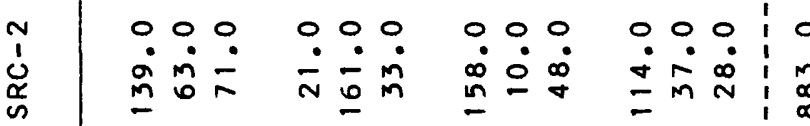

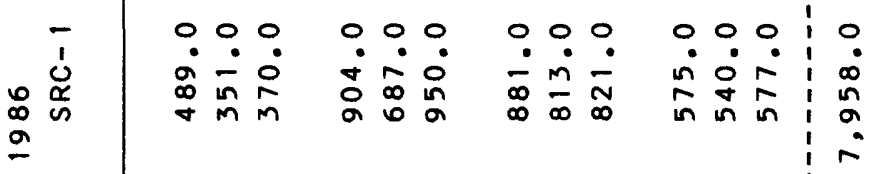

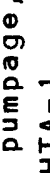

$\stackrel{5}{+}$

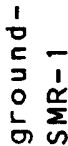

$\stackrel{0}{\frac{1}{<}}$

in

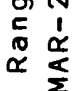

พัฒ0

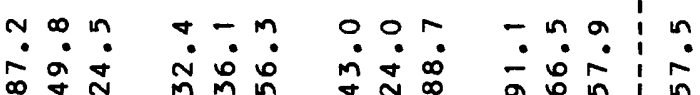

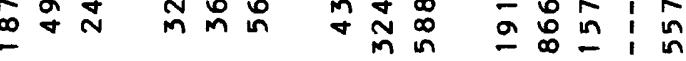

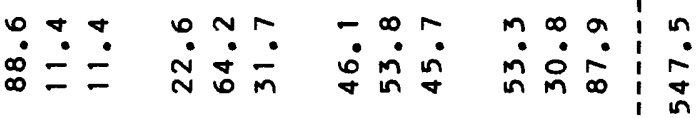

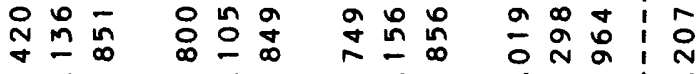

$\therefore \quad \therefore \quad \therefore$

$\frac{1}{2}$

aㅇ $0 m+\quad$ on $N m-$ i

造留莳

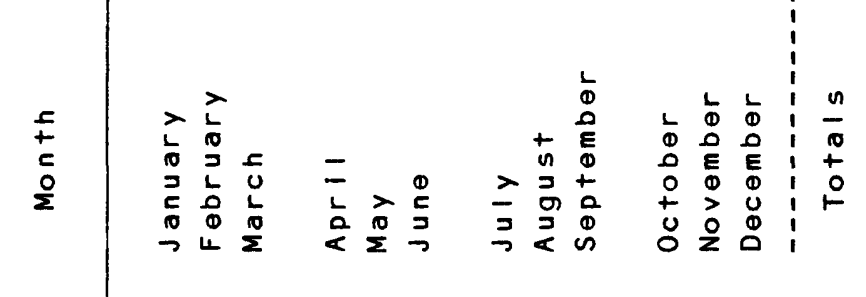




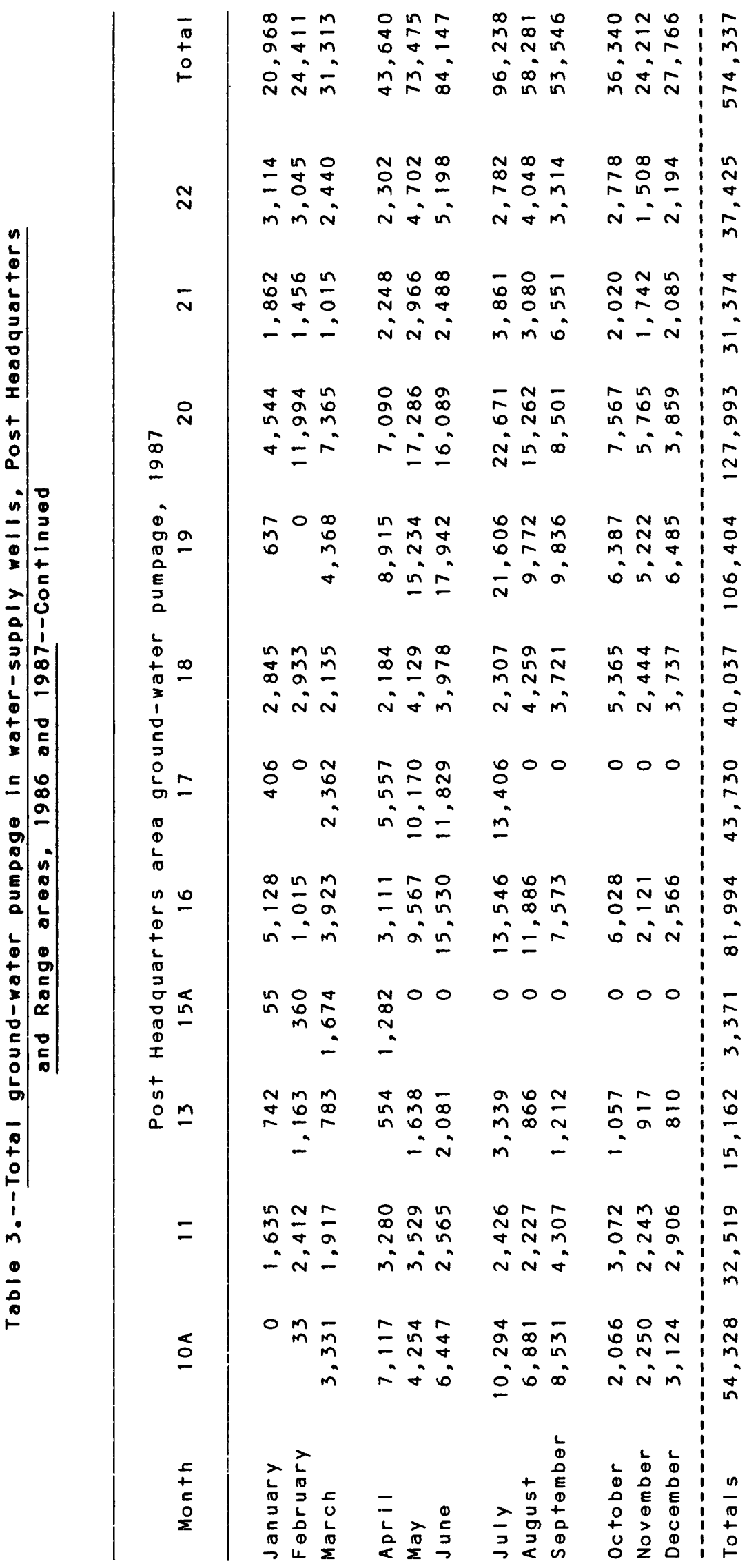




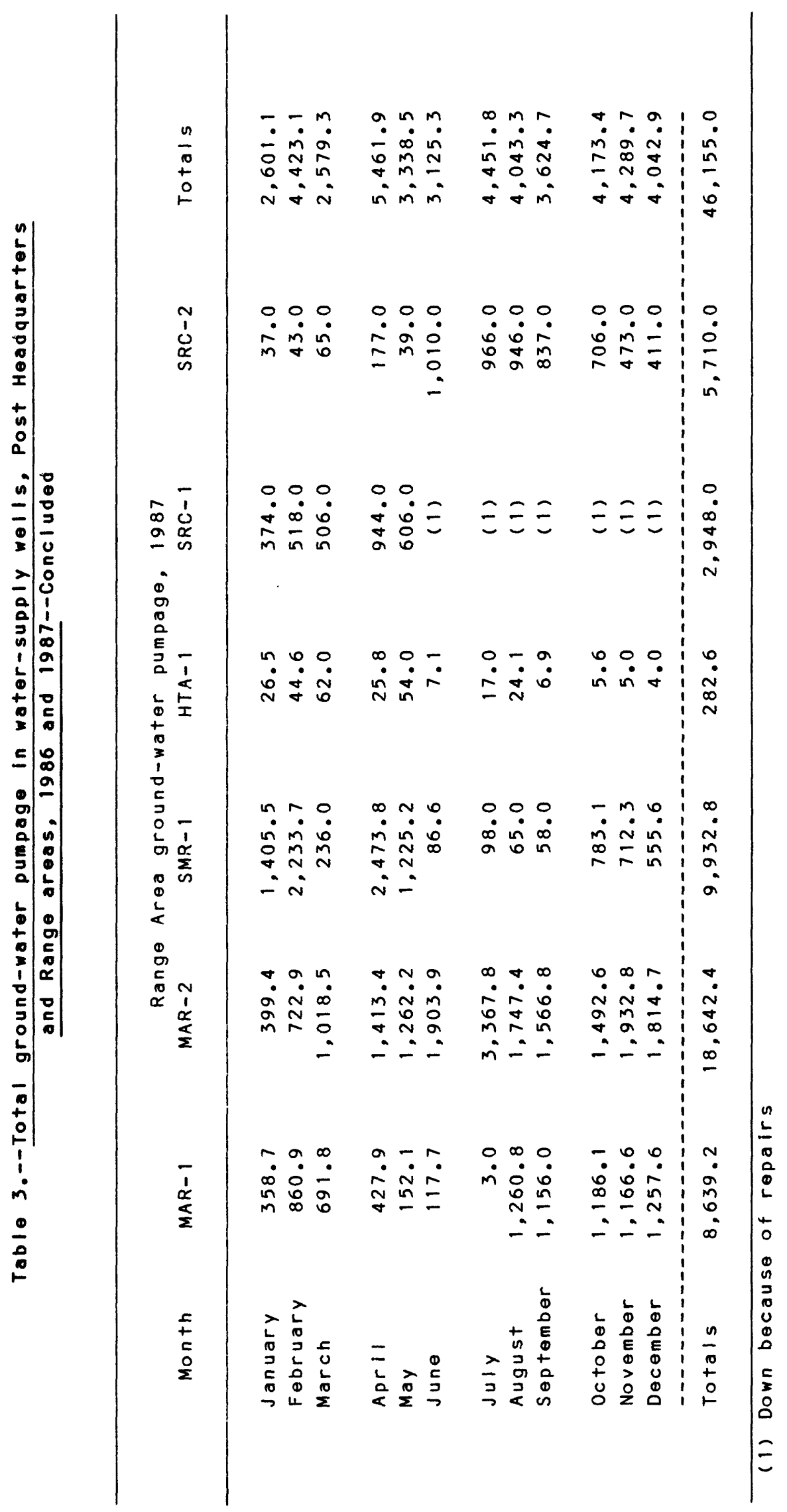



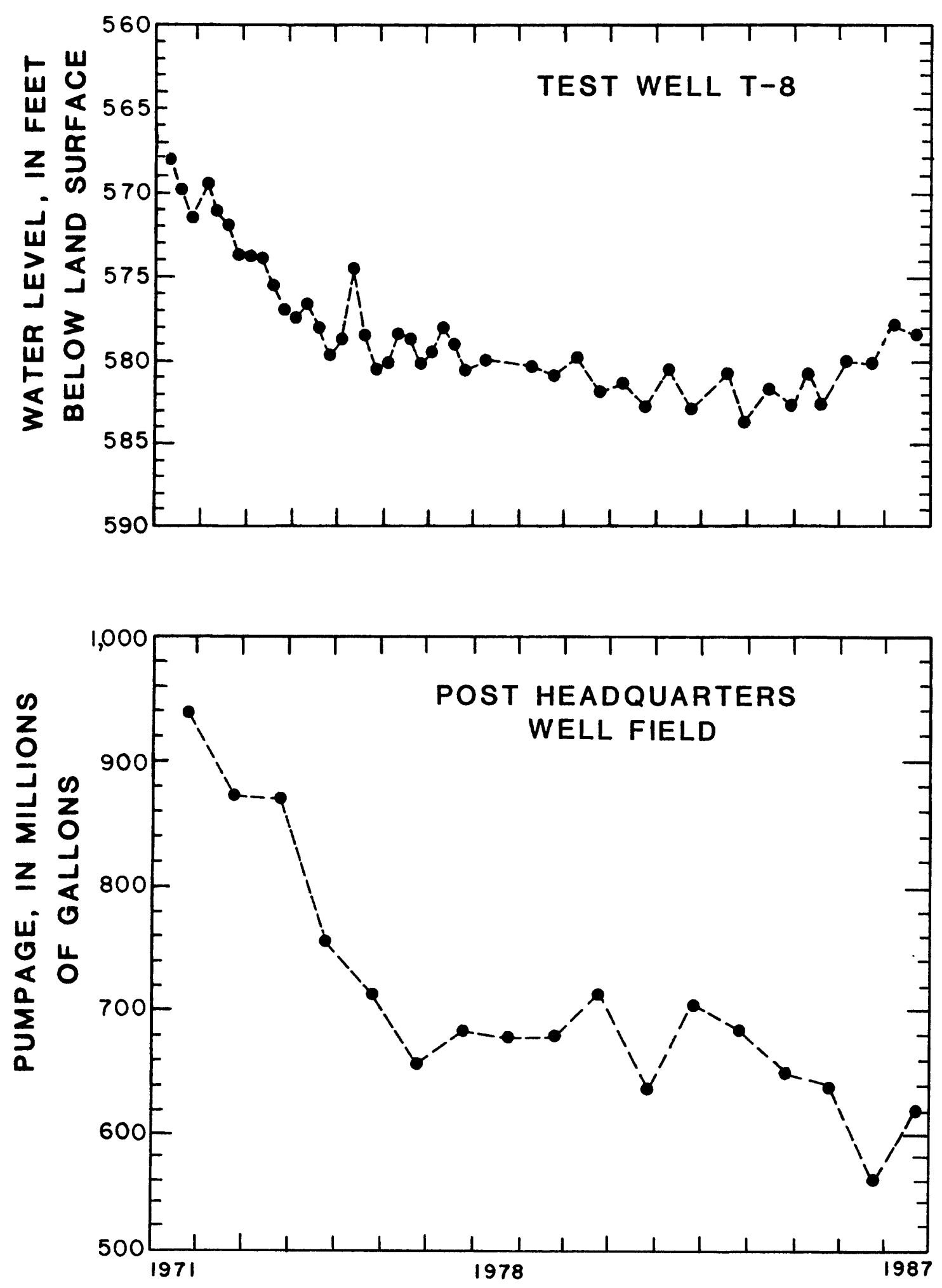

Figure 8.--Water levels in test well T-8 and yearly pumpage from the Post Headquarters well field, 1971-87. 
Table 4.--Depth to water in water-supply wells, Post Headquarters and Range areas, 1986 and 1987

\begin{tabular}{|c|c|c|c|c|c|}
\hline \multirow[b]{2}{*}{$\begin{array}{l}\text { Wel1 } \\
\text { number }\end{array}$} & \multirow[b]{2}{*}{ Location } & \multicolumn{2}{|c|}{1986} & \multicolumn{2}{|c|}{1987} \\
\hline & & $\begin{array}{l}\text { Winter } \\
\text { (feet } \\
\text { below land } \\
\text { surface) }\end{array}$ & $\begin{array}{c}\text { Summer } \\
\text { (feet } \\
\text { below land } \\
\text { surface) }\end{array}$ & $\begin{array}{l}\text { Winter } \\
\text { (feet } \\
\text { below land } \\
\text { surface) }\end{array}$ & $\begin{array}{c}\text { Summer } \\
\text { (feet } \\
\text { below land } \\
\text { surface) }\end{array}$ \\
\hline \multicolumn{6}{|c|}{ Post Headquarters area } \\
\hline SW-10A & $22 \mathrm{~S} .4 \mathrm{E} \cdot 24.212 \mathrm{a}$ & 426.38 & 435.28 & 421.70 & 423.84 \\
\hline SW-11 & $22 \mathrm{~S} .4 \mathrm{E} .24 .112$ & (1) & $348(2)$ & $358(2)$ & $348(2)$ \\
\hline SW-13 & $22 \mathrm{~S} .4 \mathrm{E} .13 .311$ & 314 (1) & $300(2)$ & $308(2)$ & 309 (2) \\
\hline SW-16 & $22 \mathrm{~S} .4 \mathrm{E} \cdot 13.432$ & 457 (1) & $457(2)$ & $452(2)$ & $458(2)$ \\
\hline SW-17 & $22 \mathrm{~S} .4 \mathrm{E} \cdot 13.241$ & 450 (1) & $450(2)$ & 432.81 & $450(2)$ \\
\hline$S W-18$ & $22 \mathrm{~S} .4 \mathrm{E} .12 .434$ & 430.27 & 433.90 & 424.75 & 426.99 \\
\hline SW-19 & $22 \mathrm{~S} .4 \mathrm{E} \cdot 12.414$ & 454.88 & 458.16 & - & 457.65 \\
\hline$S W-20$ & $22 \mathrm{~S} .4 \mathrm{E} \cdot 12.214$ & Repairs & 517.35 & 516.75 & 516.36 \\
\hline SW-21 & $22 \mathrm{~S} .5 \mathrm{E} \cdot 19.323$ & 357.06 & 359.32 & 351.67 & 354.47 \\
\hline$S W-22$ & $22 \mathrm{~S} .5 \mathrm{E} .19 .141$ & 378.22 & 381.12 & 369.05 & 373.99 \\
\hline \multicolumn{6}{|c|}{ Range area } \\
\hline HTA-1 & $21 \mathrm{~S} .4 \mathrm{E} .23 .233$ & 59.70 & 61.45 & 62.08 & -- \\
\hline $\mathrm{HTA}-3$ & $21 \mathrm{~S} .4 \mathrm{E} .14 .114$ & 49.85 & 50.74 & 49.80 & 50.15 \\
\hline MAR-1 & $19 \mathrm{~S} .5 \mathrm{E} .17 .331$ & (3) & 213.96 & 212.67 & (3) \\
\hline MAR-2 & $19 \mathrm{~S} .5 \mathrm{E} .17 .334$ & (3) & (3) & 221.77 & 219.83 \\
\hline SRC-1 & $6 \mathrm{~S} .3 \mathrm{E} .05 .232$ & 210.40 & 211.80 & 205.16 & 209.70 \\
\hline SRC-2 & $6 \mathrm{~S} \cdot 3 \mathrm{E} \cdot 05 \cdot 234$ & 213.60 & 228.79 & 212.35 & 213.20 \\
\hline \multicolumn{6}{|c|}{ (1) Air line inoperative } \\
\hline (2) $\mathrm{A}$ & line reading & & & & \\
\hline
\end{tabular}


WATER-SUPPLY WELL 1OA

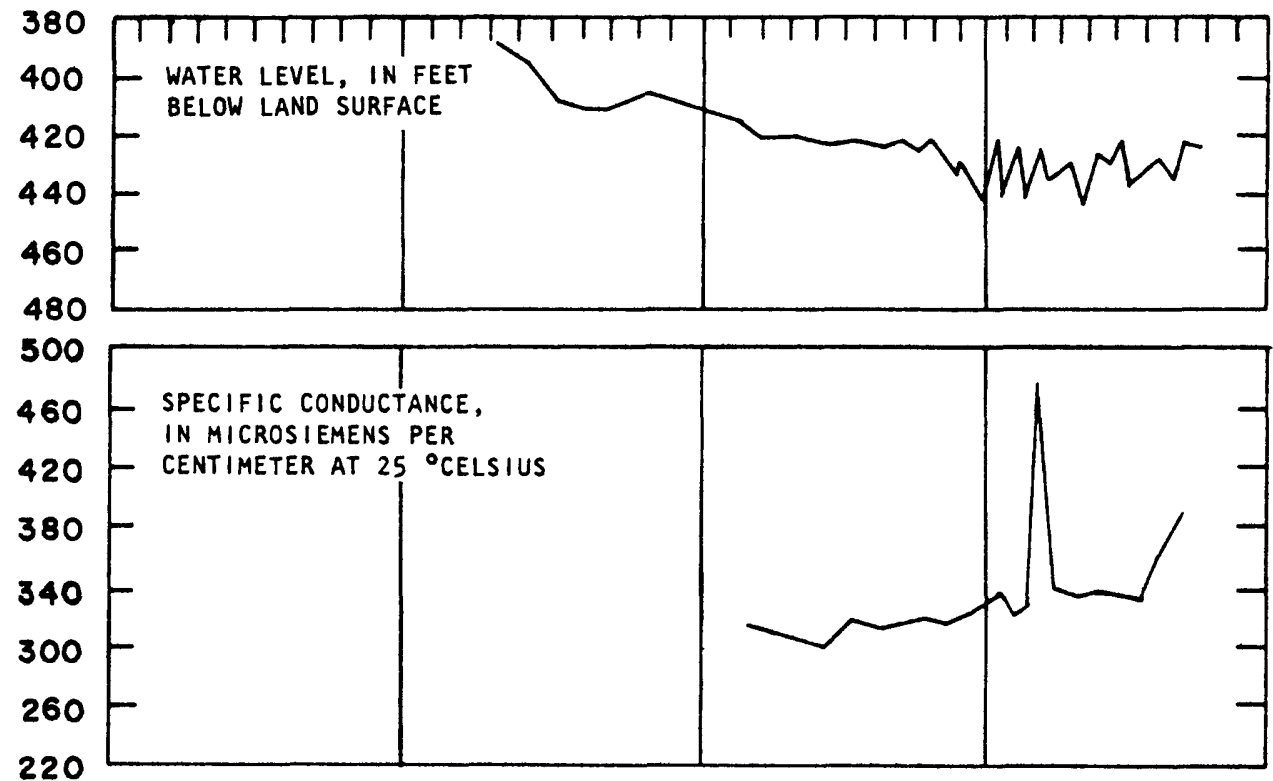

WATER-SUPPLY WELL 11
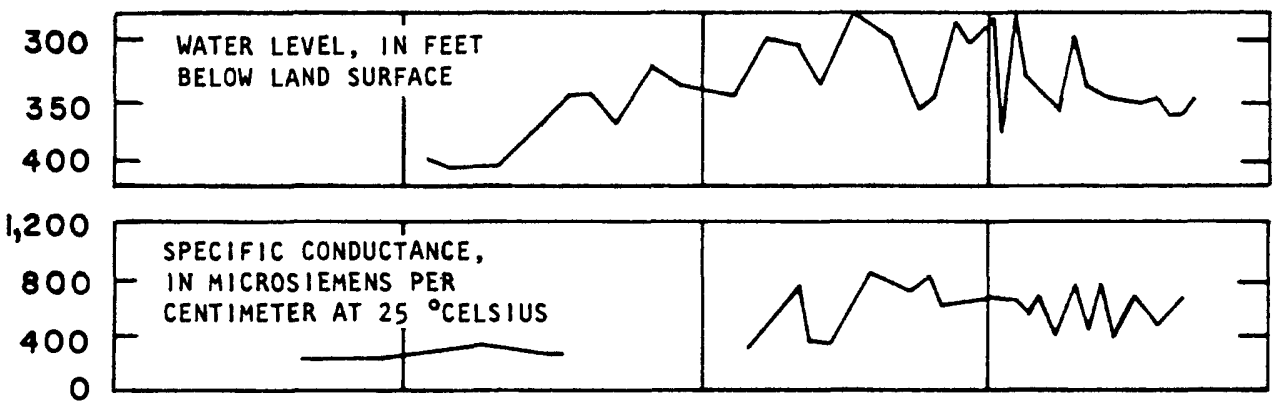

WATER-SUPPLY WELL 13
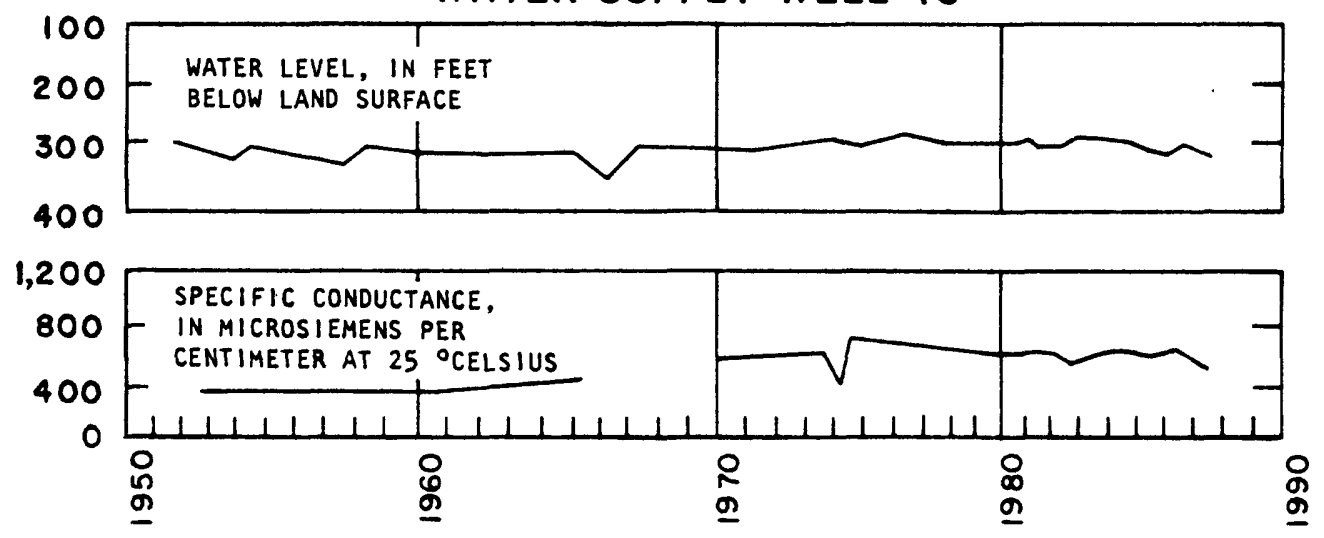

Figure 9.--Water levels and specific conductance for period of record available in selected water-supply wells, Post Headquarters area. 
WATER-SUPPLY WELL 16
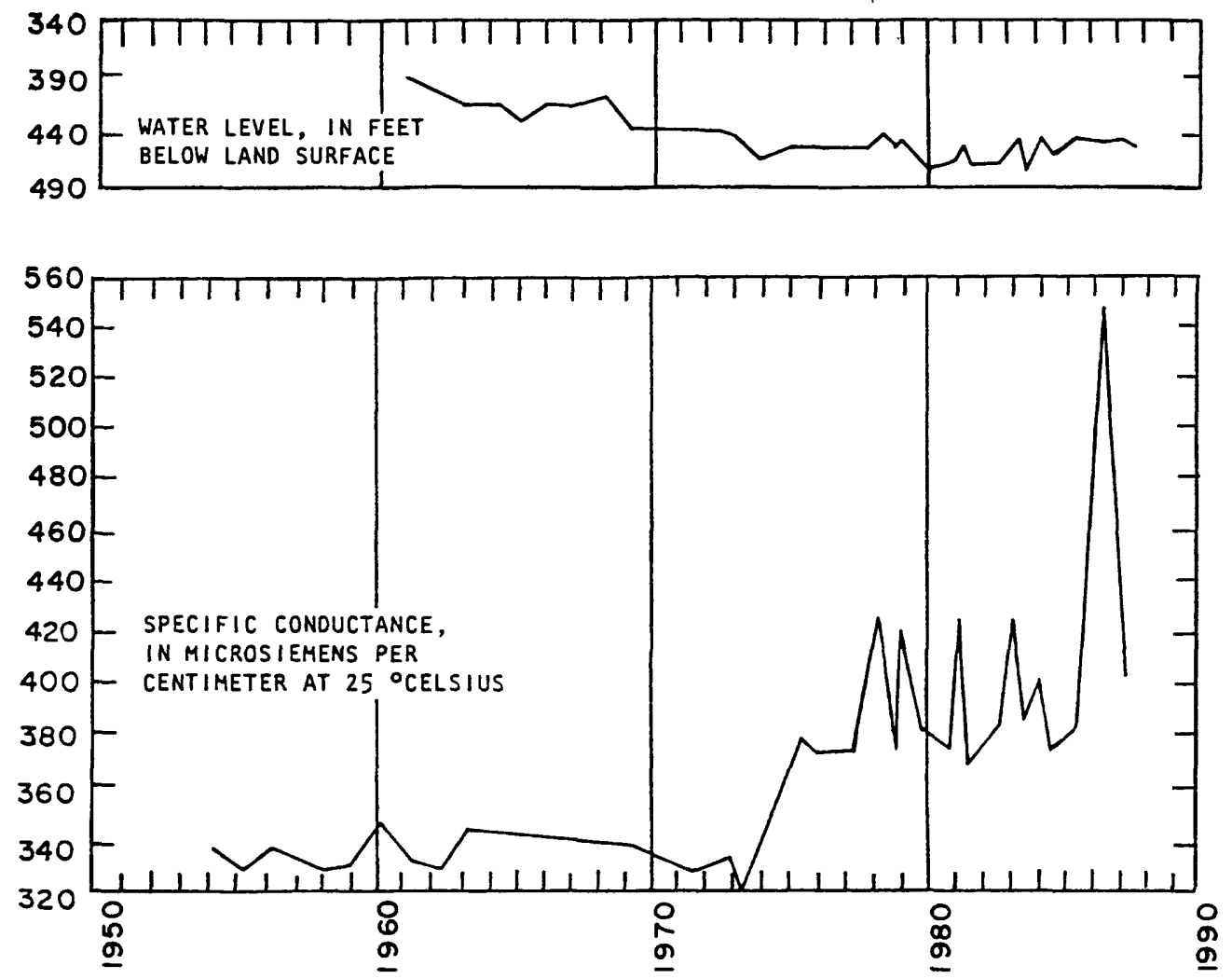

Figure 9.--Water levels and specific conductance for period of record available in selected water-supply wells, Post Headquarters area - Continued. 
WATER-SUPPLY WELL 17
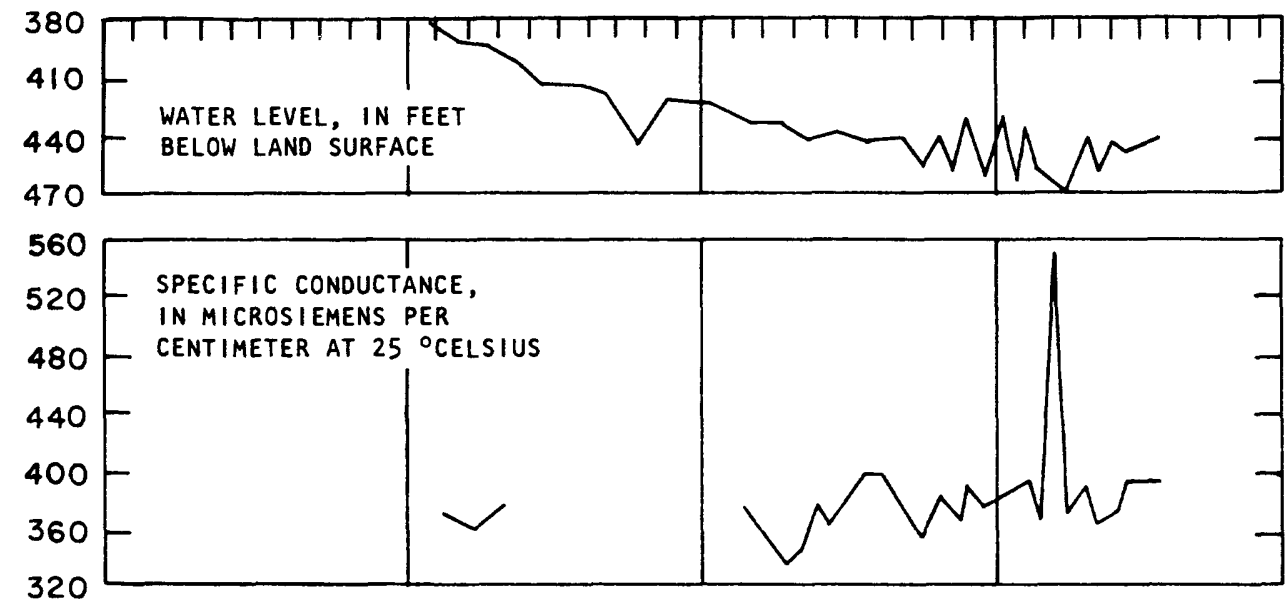

WATER-SUPPLY WELL 18
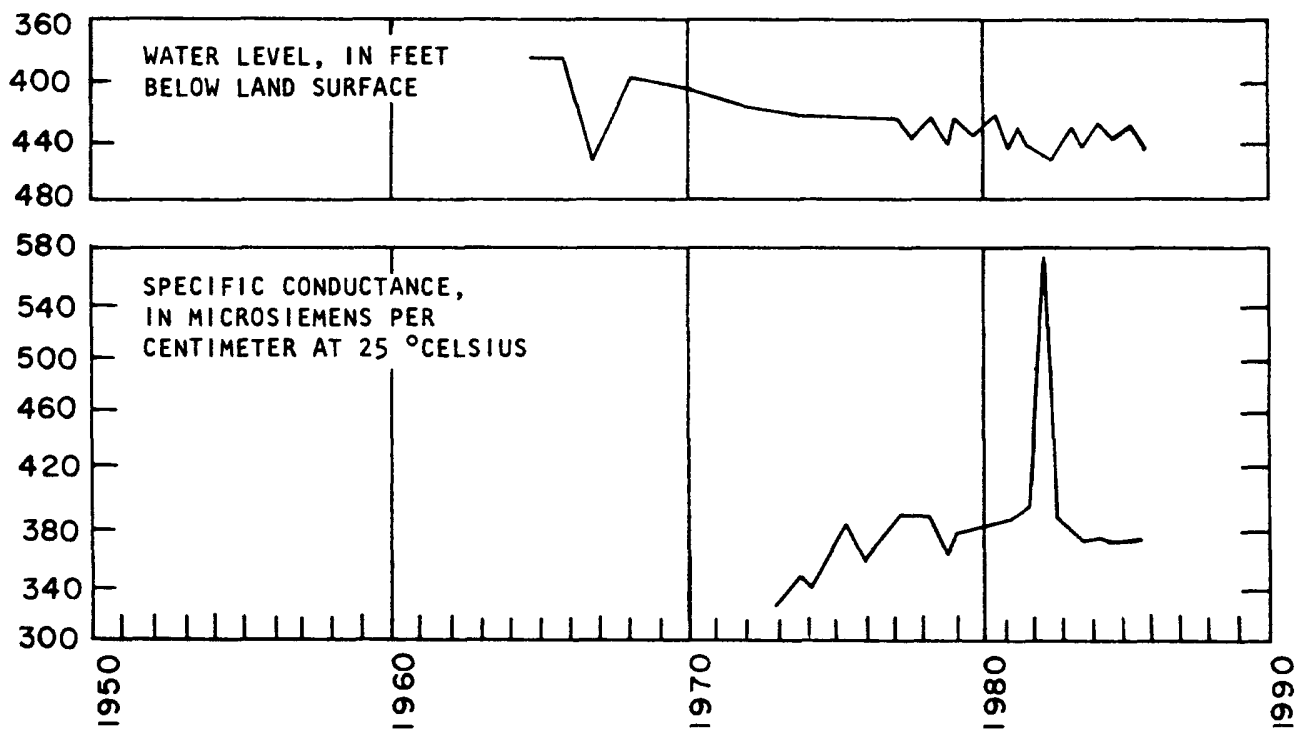

Figure 9.--Water levels and specific conductance for period of record available in selected water-supply wells, Post Headquarters area - Continued. 
WATER-SUPPLY WELL 19
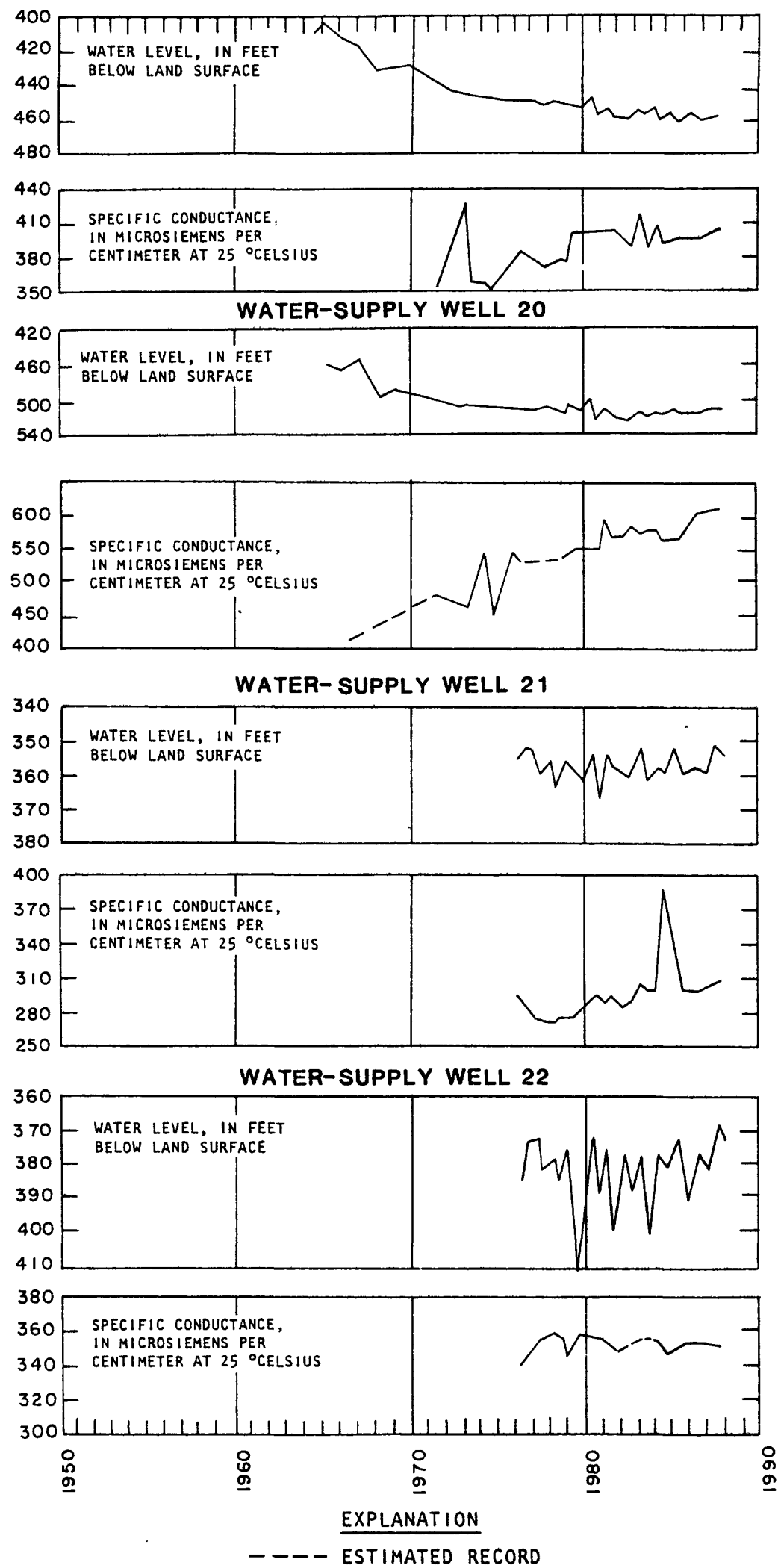

Figure 9.--Water levels and specific conductance for period of record available in selected water-supply wells, Post Headquarters area - Concluded. 


\section{Water-Level Measurements in Test Wells, Observation Wells, and Boreholes}

Depth-to-water measurements were made in 45 test and observation wells, (table 5) and 36 boreholes (table 6) in 1986 and 1987 . In 1986, 11 of the test and observation wells had seasonal water-level declines and 32 wells had seasonal water-level rises. The greatest seasonal water-level decline was 4.30 feet in test well $\mathrm{T}-7$ (excluding data from test we11 $\mathrm{T}-29$, which may be inaccurate because the well was never developed). The greatest seasonal water-level rise near the Post Headquarters well field was 2.14 feet in test we11 0S-12. Test wel1 T-10, equipped with a continuous water-level recorder, continued to have a slight, long-term water-level decline in 1986 (fig. 10). The water levels in test wells $T-7, T-8$ and $T-11$, also equipped with continuous recorders, continued to show long-term rises in 1986 (fig. 10).

Twenty-three of the test and observation wells had seasonal water-level declines in 1987. Eighteen of the test and observation wells had water-level rises, and one test we11 ( $\mathrm{T}-11)$ did not have any seasonal water-level change. The greatest seasonal water-level decline in 1987 was 7.19 feet in test we11 $\mathrm{T}-7$. The greatest seasonal water-level rise near the Post Headquarters we11 field was 1.11 feet in test well $\mathrm{T}-30$. Test we11 $\mathrm{T}-10$ continued to have a long-term water-level decline in 1987, whereas the long-term water levels in test wells $\mathrm{T}-7, \mathrm{~T}-8$, and $\mathrm{T}-11$ continued to rise (fig. 10 ).

In 1986,18 of the 36 boreholes measured had seasonal water-level rises and 18 of the boreholes had seasonal water-level declines (table 6). The greatest seasonal water-level rise was 3.95 feet in borehole $B-37$, which is about 2 miles west of the Post Headquarters well field (fig. 3). The greatest seasonal water-level decline was 1.19 feet in borehole B-54, which is about 2 miles east of the Post Headquarters well field (fig. 3). In 1987, 11 of the boreholes had seasonal water-level rises and 25 of the boreholes had seasonal declines. The greatest seasonal water-level rise was 3.29 feet in borehole B37. The greatest seasonal water-level decline was 0.94 foot in borehole B-55, which is about 2 miles east of the Post Headquarters well field (fig. 3 ). 
Table 5.--Depth to water in test and observation wells, Post Headquarters and Range areas, 1986 and 1987

\begin{tabular}{|c|c|c|c|c|c|}
\hline \multirow[b]{2}{*}{$\begin{array}{c}\text { Well } \\
\text { number }\end{array}$} & \multirow[b]{2}{*}{ Location } & \multicolumn{2}{|c|}{1986} & \multicolumn{2}{|c|}{1987} \\
\hline & & $\begin{array}{l}\text { Winter } \\
\text { (feet } \\
\text { below land } \\
\text { surface) }\end{array}$ & $\begin{array}{c}\text { Summer } \\
\text { (feet } \\
\text { below land } \\
\text { surface) }\end{array}$ & $\begin{array}{l}\text { Winter } \\
\text { (feet } \\
\text { below land } \\
\text { surface) }\end{array}$ & $\begin{array}{c}\text { Summer } \\
\text { (feet } \\
\text { below land } \\
\text { surface) }\end{array}$ \\
\hline$T-4$ & $22 \mathrm{~S} \cdot 5 \mathrm{E} \cdot 16.111$ & 227.00 & 226.92 & 226.91 & 227.18 \\
\hline$T-5$ & $22 \mathrm{~S} .5 \mathrm{E} .20 .111$ & 277.62 & 277.42 & 277.88 & 277.68 \\
\hline $\mathrm{T}-6$ & $22 \mathrm{~S} .4 \mathrm{E} \cdot 14.133$ & 189.23 & 188.81 & 188.49 & 188.11 \\
\hline $\mathrm{T}-7$ & $22 \mathrm{~S} .5 \mathrm{E} .07 \cdot 342$ & 362.60 & 366.90 & 356.73 & 363.92 \\
\hline $\mathrm{T}-8$ & $22 \mathrm{~S} .4 \mathrm{E} .11 .224$ & 580.40 & 580.31 & 577.85 & 578.15 \\
\hline $\mathrm{T}-9$ & $22 \mathrm{~S} .4 \mathrm{E} .01 .431$ & 374.02 & 372.76 & 371.85 & 370.98 \\
\hline $\mathrm{T}-10$ & $22 \mathrm{~S} .5 \mathrm{E} .05 .313$ & 274.78 & 274.84 & 274.92 & 275.00 \\
\hline $\mathrm{T}-11$ & $22 \mathrm{~S} .5 \mathrm{E} .29 .412$ & 271.69 & 271.32 & 271.49 & 271.49 \\
\hline$T-13$ & $21 \mathrm{~S} .5 \mathrm{E} .32 .222$ & 213.84 & 213.80 & 213.80 & 214.00 \\
\hline$T-14$ & $22 \mathrm{~S} .5 \mathrm{E} \cdot 15.221$ & 132.44 & 132.35 & 132.49 & 135.99 \\
\hline $\mathrm{T}-15$ & $22 \mathrm{~S} .5 \mathrm{E} \cdot 33.244$ & 179.44 & 179.27 & 179.36 & 179.23 \\
\hline $\mathrm{T}-16$ & $23 \mathrm{~S} \cdot 5 \mathrm{E} \cdot 10 \cdot 413$ & 183.75 & 182.49 & 182.64 & 186.10 \\
\hline $\mathrm{T}-17$ & $23 \mathrm{~S} \cdot 5 \mathrm{E} \cdot 27.142$ & 242.4 .1 & 242.25 & 242.52 & 242.32 \\
\hline $\mathrm{T}-18$ & $23 \mathrm{~S} .5 \mathrm{E} .05 .321$ & 237.44 & 236.80 & 236.45 & 237.65 \\
\hline $\mathrm{T}-21$ & $22 \mathrm{~S} \cdot 5 \mathrm{E} \cdot 30 \cdot 122$ & 316.04 & 315.44 & 314.52 & 313.63 \\
\hline $\mathrm{T}-22$ & $23 \mathrm{~S} .5 \mathrm{E} .05 .144$ & 189.23 & 189.38 & 188.88 & 188.52 \\
\hline $\mathrm{T}-27$ & $22 \mathrm{~S} .5 \mathrm{E} .22 .141$ & 162.45 & 162.40 & 162.23 & 162.15 \\
\hline $\mathrm{T}-28 \mathrm{~A}$ & $22 \mathrm{~S} \cdot 5 \mathrm{E} \cdot 22 \cdot 122 \mathrm{a}$ & 155.19 & 155.04 & 155.01 & 154.98 \\
\hline $\mathrm{T}-29$ & $22 \mathrm{~S} .5 \mathrm{E} .28 .122$ & 173.60 & 179.98 & 184.62 & 185.00 \\
\hline $\mathrm{T}-30$ & $22 \mathrm{~S} .5 \mathrm{E} \cdot 32 \cdot 334$ & 213.37 & 211.32 & 210.19 & 209.08 \\
\hline$T-34$ & $22 \mathrm{~S} .5 \mathrm{E} \cdot 28.234$ & 188.90 & 188.70 & 188.88 & 189.01 \\
\hline $\mathrm{T}-35$ & $22 \mathrm{~S} \cdot 5 \mathrm{E} .28 .142 \mathrm{a}$ & 186.25 & 185.36 & 185.95 & 187.39 \\
\hline $\mathrm{T}-37$ & $22 \mathrm{~S} .5 \mathrm{E} \cdot 28.142 \mathrm{~b}$ & 206.17 & 206.36 & 206.54 & 206.83 \\
\hline $\mathrm{T}-38$ & $22 \mathrm{~S} .5 \mathrm{E} .21 .211 \mathrm{a}$ & 214.46 & 214.68 & 214.11 & 214.09 \\
\hline os-9 & $22 S \cdot 5 E \cdot 31.424$ & 242.81 & 242.05 & 239.10 & 239.40 \\
\hline os-12 & $22 \mathrm{~S} .4 \mathrm{E} .23 .214$ & 229.70 & 227.56 & 224.90 & 225.47 \\
\hline TW-1 & $22 \mathrm{~S} .6 \mathrm{E} \cdot 16.233$ & 229.59 & 229.37 & 229.05 & 229.49 \\
\hline TW-2 & $22 \mathrm{~S} \cdot 6 \mathrm{E} \cdot 16.234$ & 235.90 & 235.16 & 235.49 & 235.87 \\
\hline $\mathrm{NT}-1$ & $20 \mathrm{~S} \cdot 3 \mathrm{E} \cdot 35 \cdot 341$ & 132.93 & 125.59 & 124.51 & 126.82 \\
\hline $\mathrm{NT}-2$ & $21 \mathrm{~S} .3 \mathrm{E} .02 .311$ & 177.24 & 176.93 & 176.91 & 170.24 \\
\hline
\end{tabular}


Table 5.--Depth to water in test and observation wells, Post Headquarters and Range areas, 1986 and 1987--Concluded

\begin{tabular}{|c|c|c|c|c|c|}
\hline \multirow[b]{2}{*}{$\begin{array}{l}\text { We11 } \\
\text { number }\end{array}$} & \multirow[b]{2}{*}{ Location } & \multicolumn{2}{|c|}{1986} & \multicolumn{2}{|c|}{1987} \\
\hline & & $\begin{array}{l}\text { Winter } \\
\text { (feet } \\
\text { below land } \\
\text { surface) }\end{array}$ & $\begin{array}{c}\text { Summer } \\
\text { (feet } \\
\text { below land } \\
\text { surface) }\end{array}$ & $\begin{array}{l}\text { Winter } \\
\text { (feet } \\
\text { below land } \\
\text { surface) }\end{array}$ & $\begin{array}{l}\text { Summer } \\
\text { (feet } \\
\text { below land } \\
\text { surface) }\end{array}$ \\
\hline Gregg & $22 \mathrm{~S} \cdot 6 \mathrm{E} \cdot 08 \cdot 414$ & 214.30 & $214 \cdot 18$ & 214.16 & 214.36 \\
\hline HTA (wm) & $21 \mathrm{~S} .4 \mathrm{E} .22 .222$ & 37.92 & 36.79 & 38.68 & -- \\
\hline SMR-2 & $21 \mathrm{~S} .5 \mathrm{E} \cdot 17.424$ & 320.72 & 321.71 & 321.46 & 321.08 \\
\hline SMR-3 & $20 \mathrm{~S} \cdot 5 \mathrm{E} \cdot 34.133$ & Pumping & 301.10 & 298.75 & 299.63 \\
\hline SMR-4 & $21 S \cdot 5 E \cdot 20 \cdot 344$ & 290.09 & 290.32 & 290.61 & 290.48 \\
\hline $\begin{array}{l}\text { MAR-1 } \\
\quad \text { (test) }\end{array}$ & $19 S \cdot 5 E \cdot 17 \cdot 333$ & 222.09 & 221.11 & 219.68 & 219.27 \\
\hline MAR-4 & $19 S .5 E \cdot 19.231$ & 304.39 & 302.81 & 301.56 & 301.24 \\
\hline NW30-1 & $17 \mathrm{~S} .4 \mathrm{E} .02 .211$ & 212.84 & 212.96 & 212.88 & 212.59 \\
\hline Murray & $8 \mathrm{~S} .5 \mathrm{E} .32 .334$ & 177.68 & 177.65 & 177.77 & - \\
\hline $\begin{array}{l}\text { Lucero } \\
\text { Ranch }\end{array}$ & $19 S \cdot 5 E \cdot 22 \cdot 334$ & 171.09 & 171.08 & 171.35 & 171.10 \\
\hline CW & $21 S \cdot 5 E \cdot 28.411$ & 153.24 & 153.22 & 153.40 & 153.58 \\
\hline BLM & $22 \mathrm{~S} .4 \mathrm{E} .15 .331$ & 56.37 & 58.66 & 58.40 & 59.24 \\
\hline DC- 1 & $8 \mathrm{~S} .4 \mathrm{E} .12 .444$ & - & 254.91 & - & - \\
\hline $\mathrm{RC}-3$ & $13 S .5 E \cdot 27.421$ & 35.88 & 36.60 & 35.43 & 35.93 \\
\hline RG & $15 S .5 E .29 .423$ & 30.35 & 28.19 & 28.00 & 28.56 \\
\hline
\end{tabular}


Table 6.--Depth to water in boreholes, Post Headquarters and adjacent areas, 1986 and 1987

\begin{tabular}{|c|c|c|c|c|c|}
\hline \multirow[b]{2}{*}{$\begin{array}{l}\text { Borehole } \\
\text { number }\end{array}$} & \multirow[b]{2}{*}{ Location } & \multicolumn{2}{|c|}{1986} & \multicolumn{2}{|c|}{1987} \\
\hline & & $\begin{array}{l}\text { Winter } \\
\text { (feet } \\
\text { below land } \\
\text { surface) }\end{array}$ & $\begin{array}{l}\text { Summer } \\
\text { (feet } \\
\text { below land } \\
\text { surface) }\end{array}$ & $\begin{array}{l}\text { Winter } \\
\text { (feet } \\
\text { below land } \\
\text { surface) }\end{array}$ & $\begin{array}{l}\text { Summer } \\
\text { (feet } \\
\text { below land } \\
\text { surface) }\end{array}$ \\
\hline $\mathrm{B}-2$ & $22 \mathrm{~S} \cdot 5 \mathrm{E} \cdot 28 \cdot 124$ & 196.10 & 196.08 & 196.19 & 196.18 \\
\hline$B-3$ & $22 \mathrm{~S} \cdot 5 \mathrm{E} \cdot 28 \cdot 142$ & 202.01 & 201.98 & 202.08 & 202.38 \\
\hline$B-4$ & $22 \mathrm{~S} \cdot 5 \mathrm{E} \cdot 28 \cdot 233$ & 195.98 & 195.88 & 196.06 & 196.67 \\
\hline B -5 & $22 \mathrm{~S} \cdot 5 \mathrm{E} \cdot 33.223$ & 187.30 & 187.07 & 187.23 & 187.03 \\
\hline$B-6$ & $23 \mathrm{~S} .5 \mathrm{E} .01 .113$ & 133.82 & 133.74 & 133.88 & 133.62 \\
\hline$B-9$ & $22 \mathrm{~S} .5 \mathrm{E} .21 .211$ & 225.05 & 224.98 & 224.73 & 224.83 \\
\hline$B-10$ & $22 \mathrm{~S} .5 \mathrm{E} \cdot 19.414$ & 305.18 & 304.99 & 303.85 & 302.64 \\
\hline B -13 & $22 \mathrm{~S} .5 \mathrm{E} .08 .141$ & 245.40 & 245.64 & 245.76 & 245.89 \\
\hline$B-14$ & $22 \mathrm{~S} .5 \mathrm{E} .03 .221$ & 112.73 & 112.65 & 112.63 & 112.86 \\
\hline$B-15$ & $22 \mathrm{~S} \cdot 5 \mathrm{E} .05 .242$ & 175.31 & 175.40 & 175.65 & 175.70 \\
\hline$B-16$ & $21 \mathrm{~S} \cdot 5 \mathrm{E} \cdot 34 \cdot 213$ & 109.80 & 109.79 & 109.80 & 110.00 \\
\hline$B-17$ & $21 \mathrm{~s} .5 \mathrm{E} \cdot 33.242$ & 112.04 & 112.11 & 112.10 & 112.28 \\
\hline $\mathrm{B}-18$ & $21 \mathrm{~S} .5 \mathrm{E} .23 .134$ & 104.78 & 104.88 & 104.85 & 104.94 \\
\hline$B-20$ & $22 \mathrm{~S} .4 \mathrm{E} \cdot 14.134$ & 349.29 & 348.80 & 348.55 & 348.12 \\
\hline$B-23$ & $22 \mathrm{~S} \cdot 5 \mathrm{E} \cdot 16 \cdot 111$ & 225.39 & 225.41 & 225.35 & 225.59 \\
\hline$B-26$ & $21 \mathrm{~S} \cdot 6 \mathrm{E} \cdot 32.114$ & 141.07 & 141.31 & 141.07 & 141.38 \\
\hline$B-27$ & $21 \mathrm{~S} \cdot 6 \mathrm{E} \cdot 17 \cdot 314$ & 120.06 & 120.00 & 119.82 & 120.02 \\
\hline$B-28$ & $21 \mathrm{~S} .5 \mathrm{E} .02 .341$ & 140.43 & 140.50 & 140.49 & 140.51 \\
\hline$B-30$ & $20 \mathrm{~S} \cdot 5 \mathrm{E} .23 .213$ & 89.71 & 89.79 & 89.72 & 89.69 \\
\hline B-31 & $20 \mathrm{~S} \cdot 6 \mathrm{E} \cdot 29 \cdot 123$ & 123.44 & 123.45 & 123.18 & 123.60 \\
\hline$B-34$ & $21 \mathrm{~S} .5 \mathrm{E} .01 .221$ & 126.37 & 126.46 & 126.50 & 126.52 \\
\hline$B-36$ & $22 \mathrm{~S} \cdot 4 \mathrm{E} .01 .323$ & 211.64 & 211.46 & 211.29 & 211.05 \\
\hline$B-37$ & $22 \mathrm{~S} .4 \mathrm{E} .11 .344$ & 385.29 & 381.34 & 377.22 & 373.93 \\
\hline$B-38$ & $20 \mathrm{~S} .6 \mathrm{E} .11 .234$ & 129.85 & 129.88 & 129.72 & 129.90 \\
\hline$B-39$ & $21 \mathrm{~S} .6 \mathrm{E} .02 .142$ & 156.48 & 156.39 & 155.93 & 156.45 \\
\hline$B-40$ & $21 \mathrm{~S} \cdot 6 \mathrm{E} \cdot 26 \cdot 142$ & 188.78 & 188.66 & 188.15 & 188.80 \\
\hline B-42 & $22 \mathrm{~S} .4 \mathrm{E} .11 .444$ & 366.09 & 366.76 & 365.16 & 363.19 \\
\hline$B-46$ & $21 \mathrm{~S} .5 \mathrm{E} \cdot 27.113$ & 136.30 & $136 \cdot 38$ & 136.46 & 136.52 \\
\hline$B-47$ & $22 \mathrm{~S} \cdot 5 \mathrm{E} .08 .334$ & 274.78 & 274.93 & 274.07 & 274.85 \\
\hline$B-48$ & $22 \mathrm{~S} \cdot 6 \mathrm{E} \cdot 31 \cdot 322$ & 204.73 & 204.62 & 204.74 & 204.54 \\
\hline & $22 \mathrm{~S} \cdot 5 \mathrm{E} \cdot 07.242$ & 307.78 & $306 \cdot 10$ & 308.14 & 308.32 \\
\hline$B-51$ & $22 \mathrm{~S} \cdot 5 \mathrm{E} \cdot 26 \cdot 312$ & 146.36 & 146.39 & 146.30 & 146.31 \\
\hline$B-52$ & $22 \mathrm{~S} .5 \mathrm{E} .09 .113$ & 211.25 & 211.29 & 211.25 & 211.50 \\
\hline$B-54$ & $22 \mathrm{~S} \cdot 5 \mathrm{E} \cdot 16.111$ & 229.02 & 230.21 & 230.12 & 230.30 \\
\hline$B-55$ & $22 \mathrm{~S} .5 \mathrm{E} .09 .113$ & 215.07 & 215.14 & 214.08 & 215.02 \\
\hline$B-56$ & $22 \mathrm{~S} \cdot 5 \mathrm{E} \cdot 30 \cdot 424$ & 275.56 & 274.50 & 273.59 & 272.74 \\
\hline
\end{tabular}



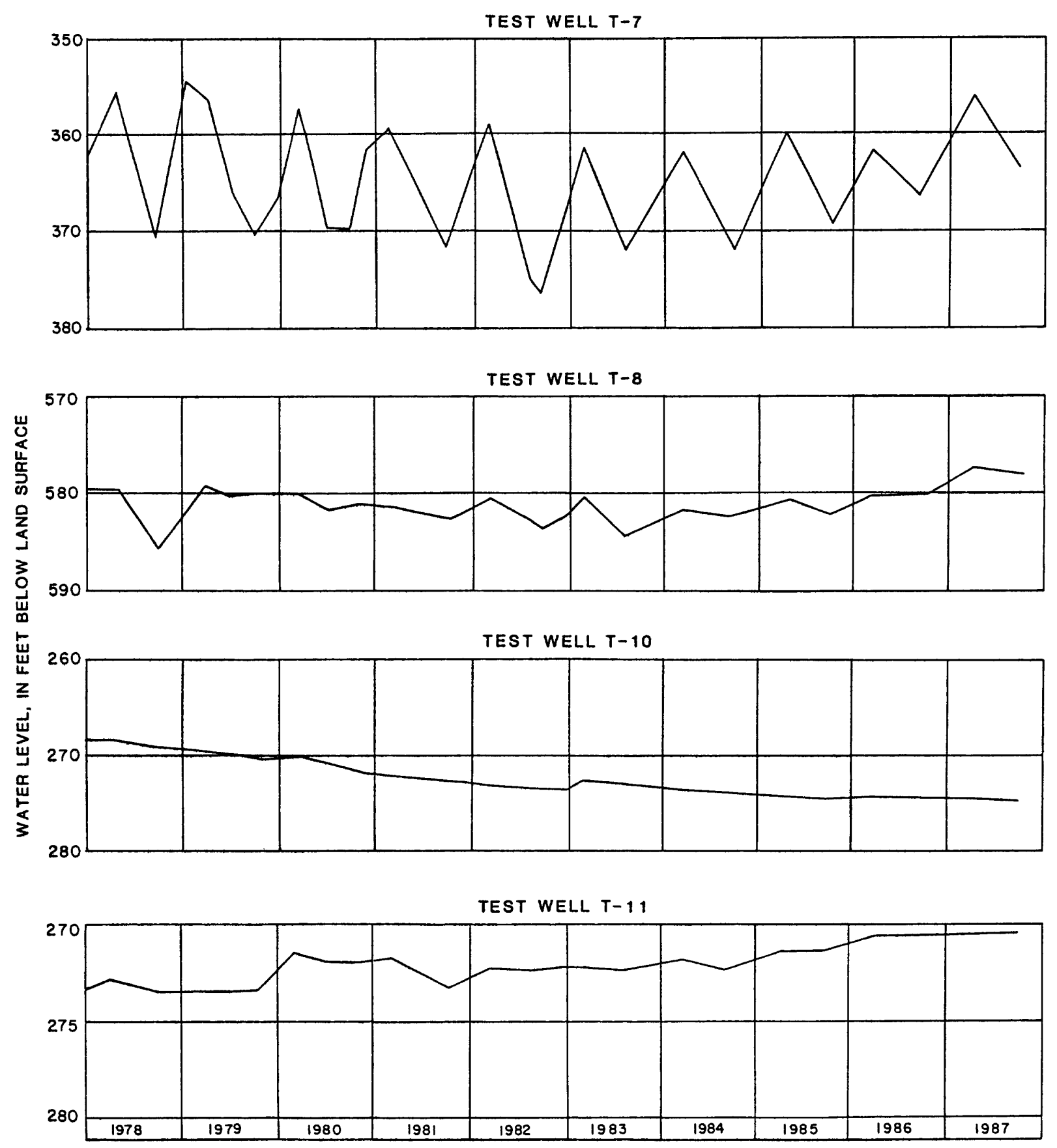

Figure 10.--Water levels in test wells T-7, T-8, T-10, and T-11, 1978-87. 


\section{Chemical Quality}

Eight water samples were collected in 1986 and 1987 from five watersupply wells in the Post Headquarters area, one water-supply well in the Range area, and one test well in the Range area for chemical analysis (table 7). The long-term specific conductance of water samples collected from 10 watersupply wells in the Post Headquarters area is shown in figure 9. Monthly specific conductance and pumpage from 1986 and 1987 for 11 water-supply wel1s are shown in figure 11. The dissolved-sodium concentration ranged from 23 milligrams per liter in the sample from water-supply we11 SW-10A to 3,900 milligrams per liter in water from test well Fluor-1. The dissolved-chloride concentration ranged from 20 milligrams per liter in the sample from watersupply well SW-10A to 4,100 milligrams per liter in water from test well Fluor-1.

Sixteen water samples were collected from four test wells in the Post Headquarters area for analysis of volatile organic compounds in 1987 (table 8). The analyses determined that trace amounts of dichlorobromomethane may be present in test well E-1, traces of chloroform may be present in test we11s E-1 and E-4, and traces of toluene may be present in test wells E-1 and E-2. These concentrations however, with one exception, are less than one microgram per liter; thus the detection levels may be questionable.

Twenty-eight water samples, 17 from Post Headquarters area test and observation wells and 11 from Post Headquarters area water-supply wells, were collected for specific-conductance analyses in 1986 and 1987 (table 9). In 1986, the specific conductance ranged from 248 microsiemens per centimeter at 25 degrees Celsius in water from test well $\mathrm{T}-17$ to 1,920 microsiemens per centimeter at 25 degrees Celsius in water from test well $\mathrm{T}-14$. In 1987 , the specific conductance ranged from 250 microsiemens per centimeter at 25 degrees Celsius in water from test well $\mathrm{T}-17$ to 1,650 microsiemens per centimeter at 25 degrees Celsius in water from test well T-14. 


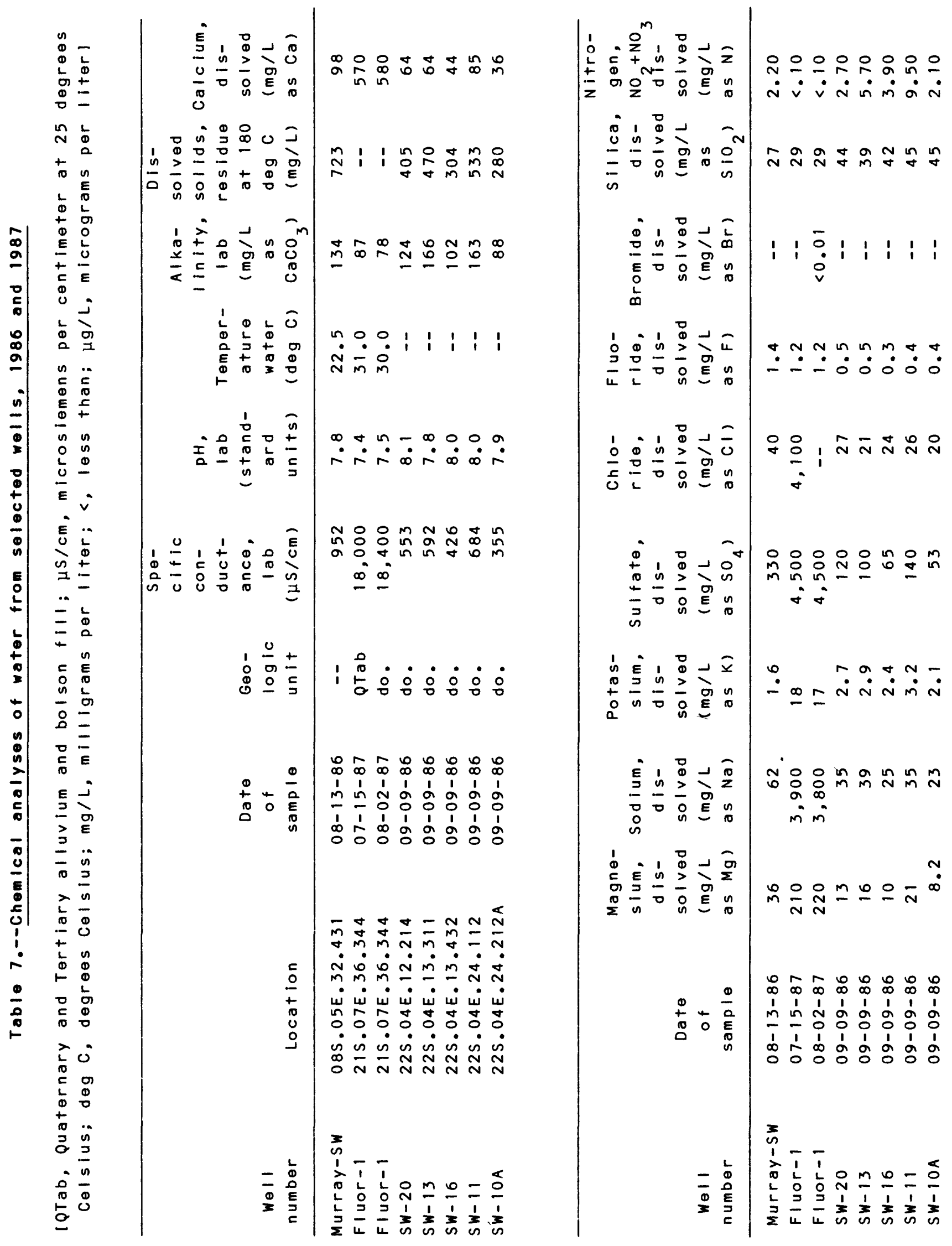




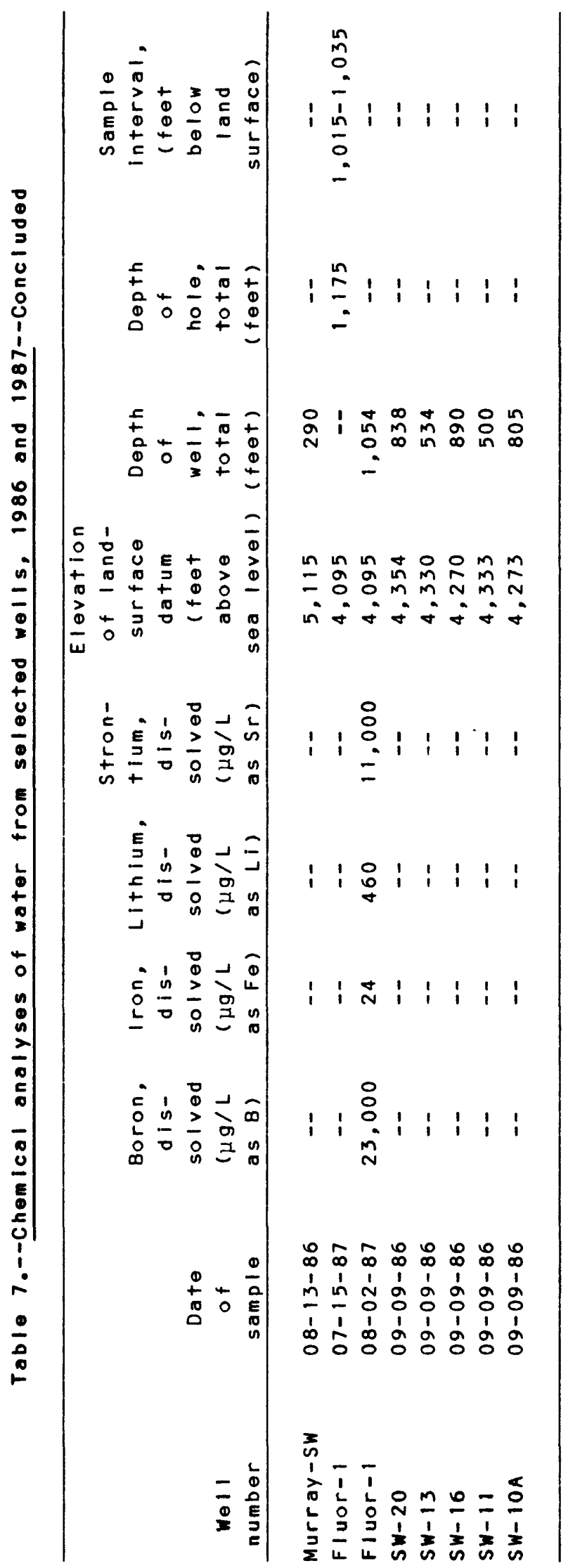



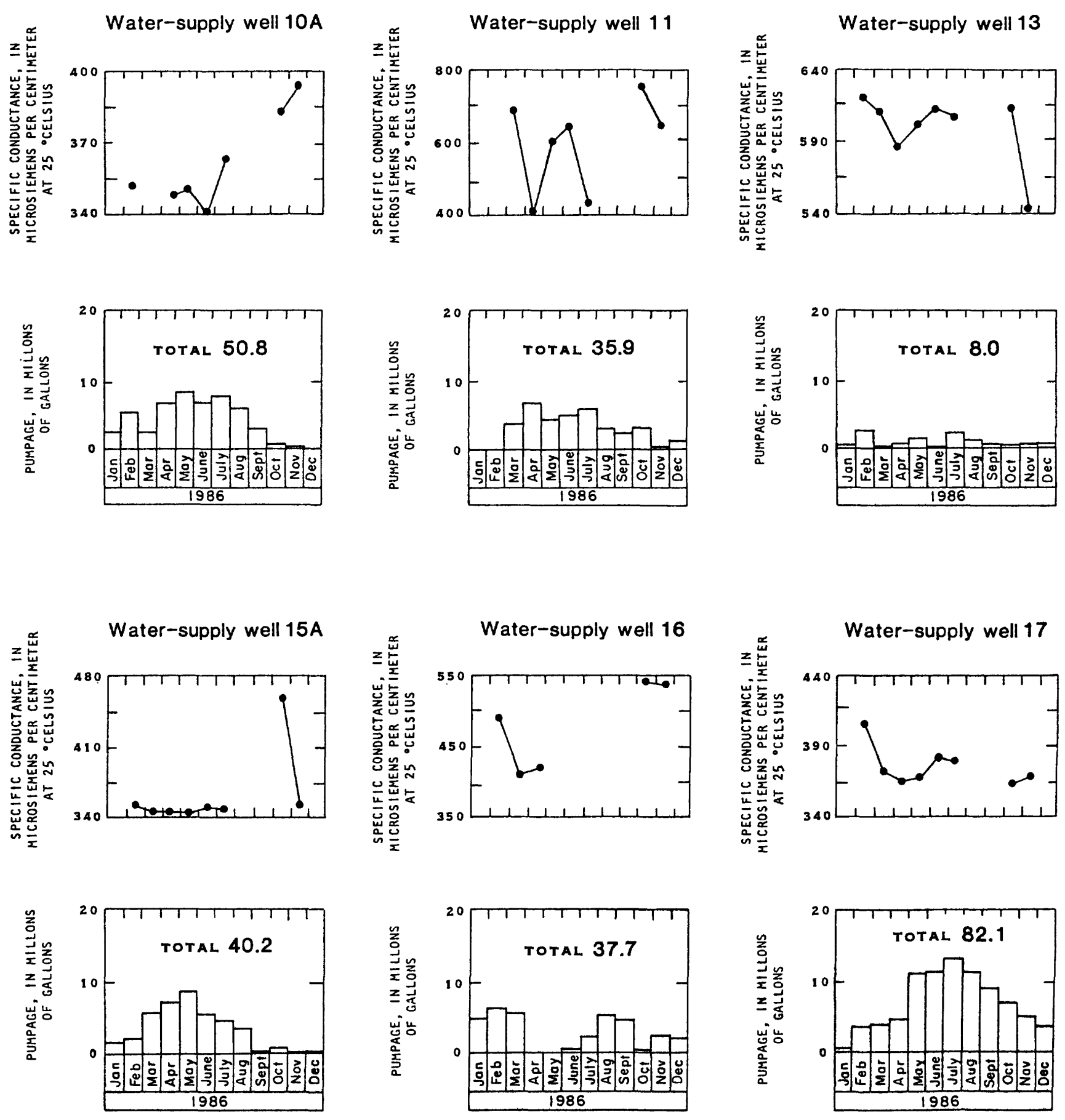

Figure 11.--Monthly specific conductance and pumpage for Post Headquarters water-supply wells, 1986 and 1987. 

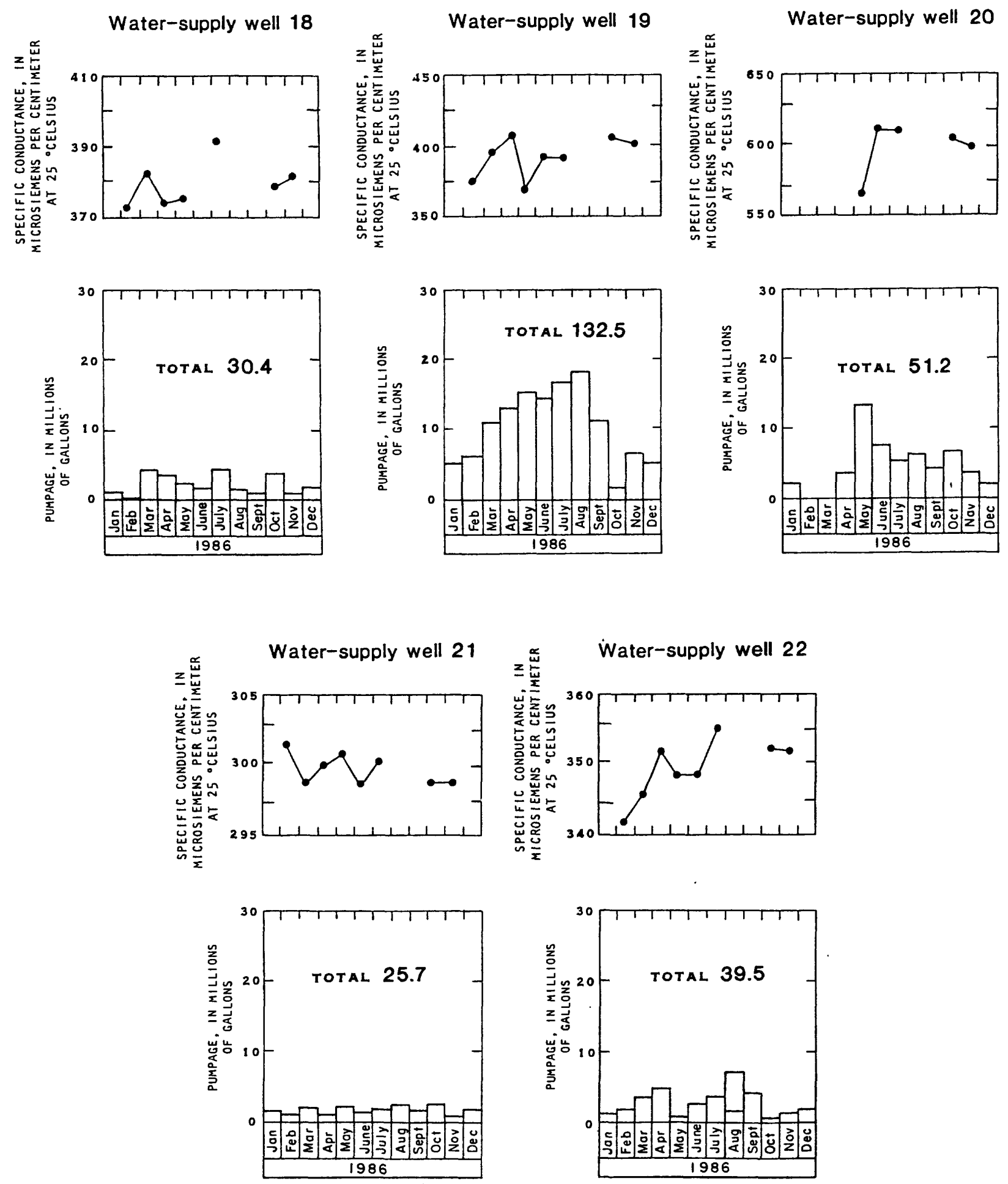

Figure 11.--Monthly specific conductance and pumpage for Post Headquarters water-supply wells, 1986 and 1987 - Continued. 

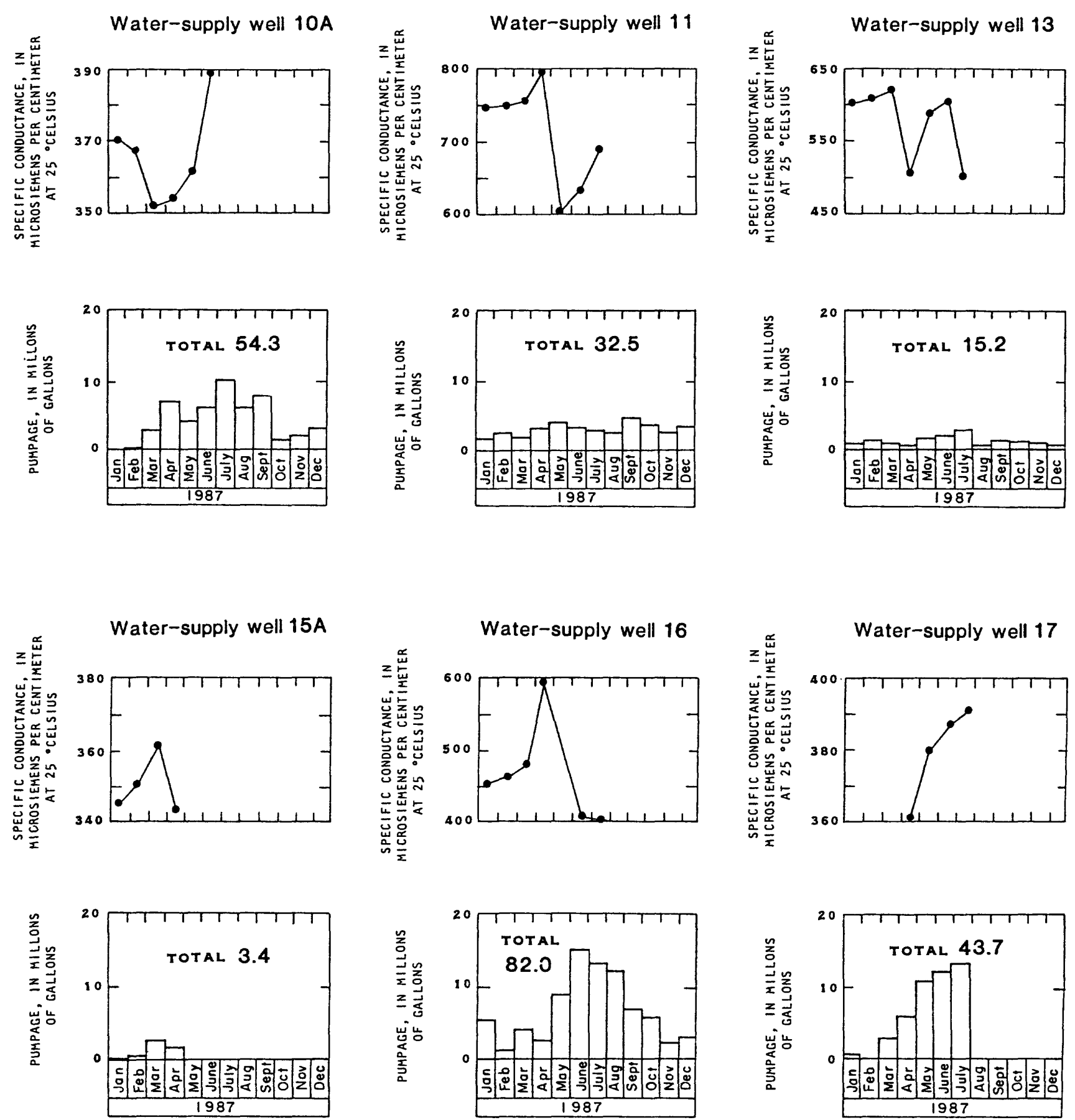

Figure 11.--Monthly specific conductance and pumpage for Post Headquarters water-supply wells, 1986 and 1987 - Continued. 

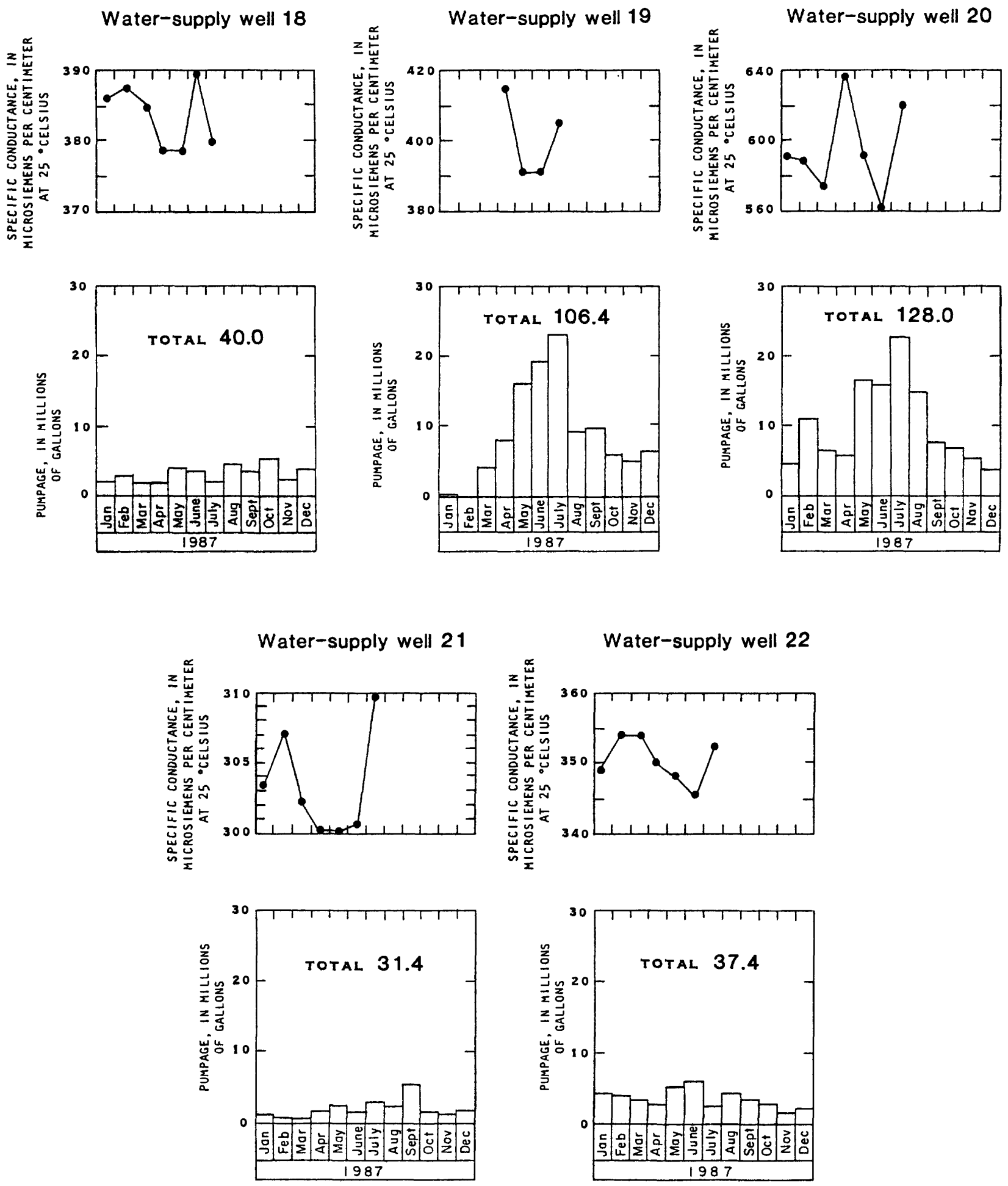

Figure 11.--Monthly specific conductance and pumpage for Post Headquarters water-supply wells, 1986 and 1987 - Concluded. 


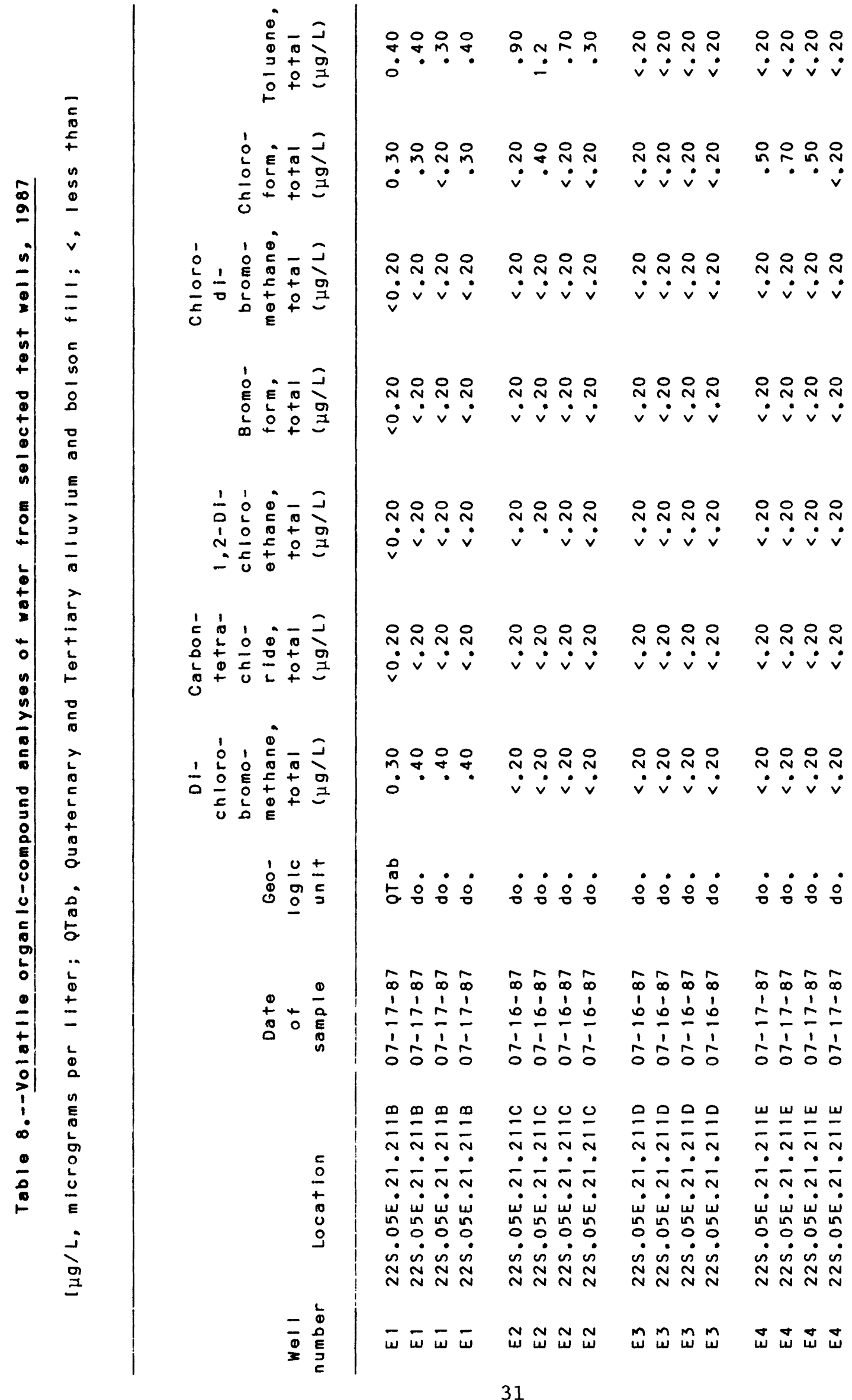




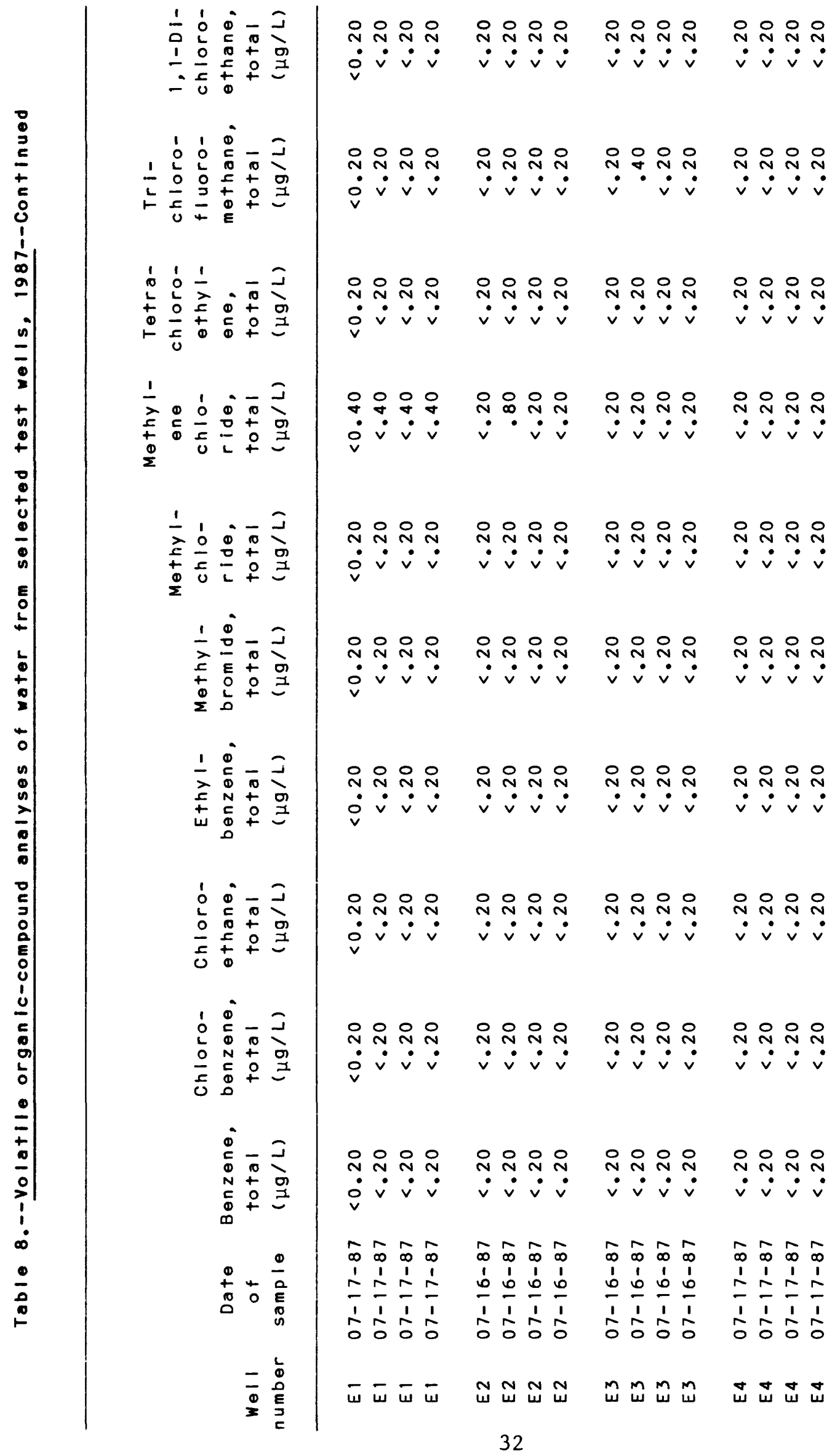




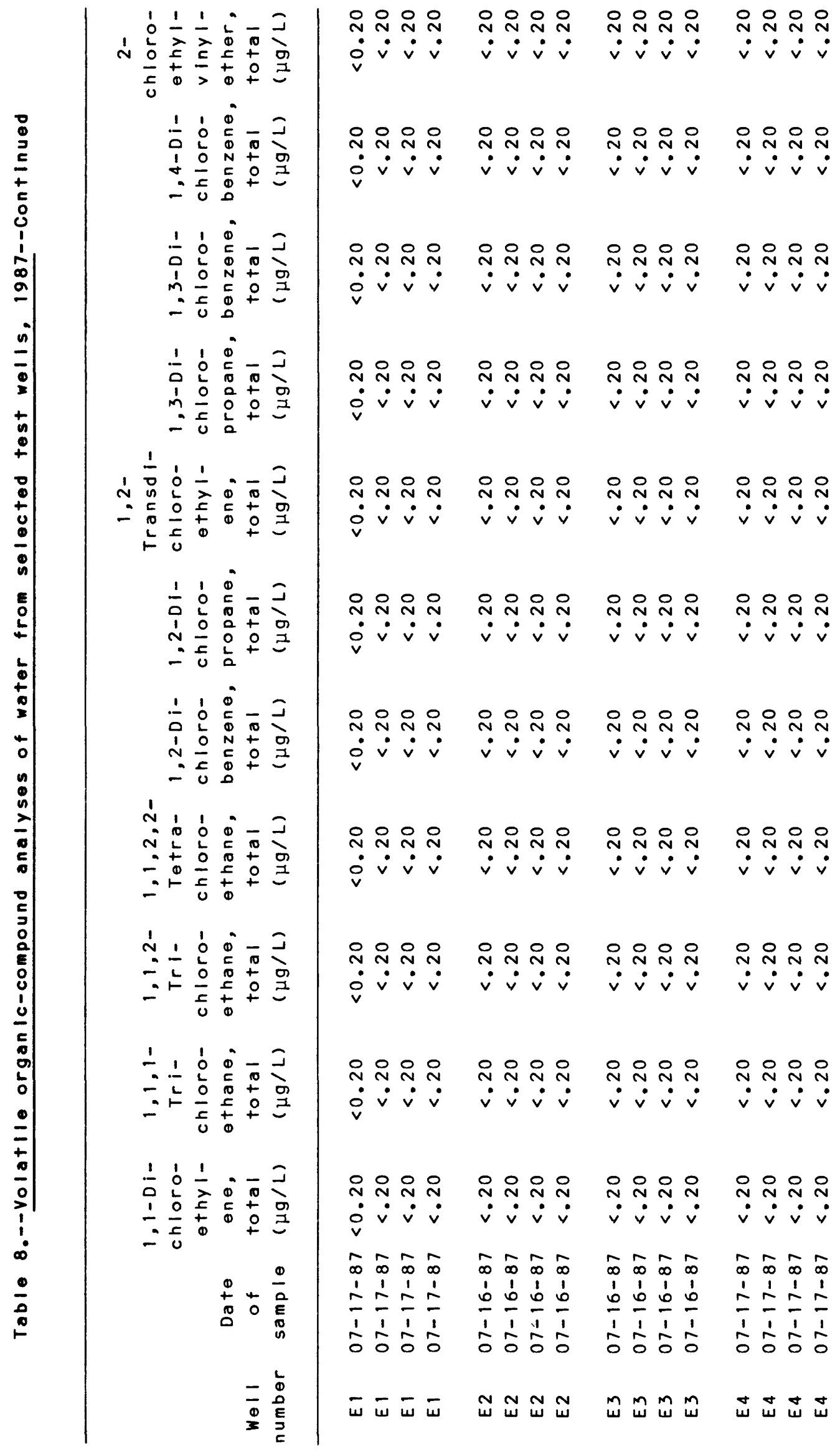




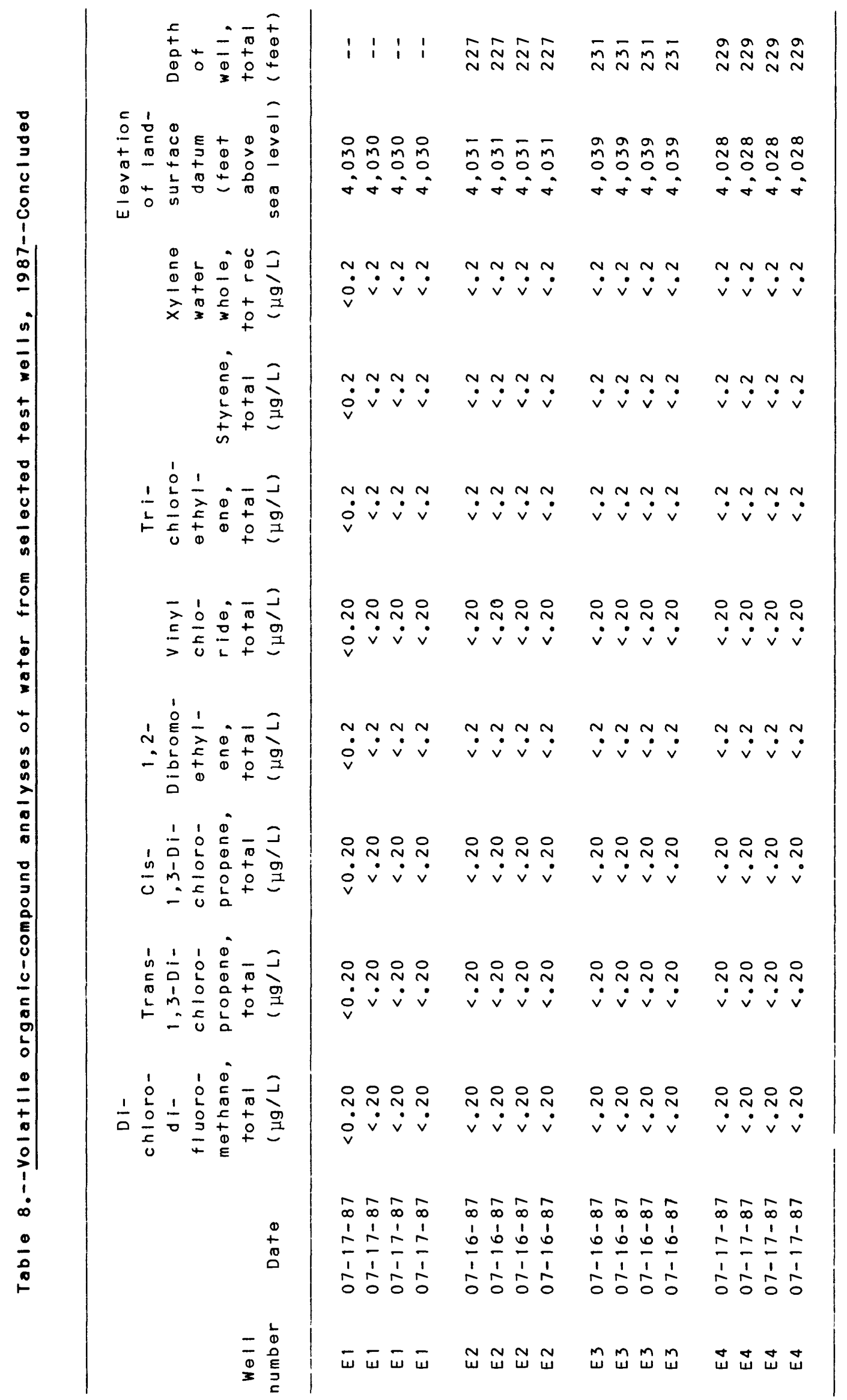


Table 9.--Specific conductance of water samples collected

from test and water-supply wells in the Post Headquarters

area, summers of 1986 and 1987

[ $\mu \mathrm{S} / \mathrm{cm}$, microsiemens per centimeter at 25 degrees Celsius]

\begin{tabular}{|c|c|c|c|}
\hline We11 number & $\begin{array}{c}1986 \\
\text { specific } \\
\text { conductance, lab } \\
(\mu \mathrm{S} / \mathrm{cm})\end{array}$ & $\begin{array}{c}1987 \\
\text { specific } \\
\text { conductance, lab } \\
(\mu \mathrm{S} / \mathrm{cm})\end{array}$ & $\begin{array}{c}\text { Sampling point } \\
\text { (feet below land } \\
\text { surface) }\end{array}$ \\
\hline \multicolumn{4}{|l|}{ Test we11s } \\
\hline $\mathrm{T}-4$ & 313 & 305 & 325 \\
\hline$T-5$ & 368 & 370 & 330 \\
\hline$T-6$ & 438 & 405 & 350 \\
\hline $\mathrm{T}-7$ & 346 & 345 & 440 \\
\hline $\mathrm{T}-7$ & --- & 600 & 960 \\
\hline $\mathrm{T}-8$ & 640 & 690 & 610 \\
\hline $\mathrm{T}-8$ & --- & 640 & 910 \\
\hline $\mathrm{T}-9$ & 855 & 850 & 550 \\
\hline $\mathrm{T}-10$ & 334 & 330 & 530 \\
\hline $\mathrm{T}-11$ & 265 & 270 & 570 \\
\hline os -12 & 449 & 465 & 330 \\
\hline $\mathrm{T}-13$ & 468 & 475 & 330 \\
\hline $\mathrm{T}-14$ & 1,920 & 1,650 & 300 \\
\hline $\mathrm{T}-15$ & 293 & 285 & 448 \\
\hline $\mathrm{T}-16$ & 360 & 285 & 480 \\
\hline $\mathrm{T}-17$ & 248 & 250 & 440 \\
\hline $\mathrm{T}-18$ & 692 & 710 & 635 \\
\hline \multicolumn{4}{|c|}{ Water-supply wells } \\
\hline $\mathrm{SW}-10 \mathrm{~A}$ & 364 & 390 & Pumping \\
\hline SW-11 & 430 & 690 & Do. \\
\hline SW-13 & 609 & 500 & Do. \\
\hline$S W-15 A$ & 344 & 345 & Do. \\
\hline SW-16 & 548 & 400 & Do. \\
\hline SW-17 & 380 & 390 & Do. \\
\hline SW-18 & 391 & 380 & Do. \\
\hline SW-19 & 395 & 405 & Do. \\
\hline SW-20 & 614 & 620 & Do. \\
\hline$S W-21$ & 300 & 310 & Do. \\
\hline SW-22 & 356 & 352 & Do. \\
\hline
\end{tabular}




\section{SELECTED REFERENCES}

Cooper, J.B., 1970, Summary records of supply wells and test wells in the Post Headquarters area, White Sands Missile Range, New Mexico: U.S. Geological Survey open-file report, 202 p.

1973, Summary records of test and supply wells in Range areas, White Sands Missile Range, New Mexico: U.S. Geological Survey open-file report, $132 \mathrm{p}$.

Gross, Jim, 1985, Investigation of the potential for geothermal energy at White Sands Missile Range: Las Cruces, New Mexico State University Energy Institute, $40 \mathrm{p}$.

Kelly, T.E., 1973, Summary of ground-water data at Post Headquarters and adjacent areas, White Sands Missile Range: U.S. Geological Survey openfile report, $66 \mathrm{p}$.

Myers, R.G., and Pinckley, K.M., 1985, Test we11s T23, T29, and T30, White Sands Missile Range and Fort Bliss Military Reservation, Doña Ana County, New Mexico: U.S. Geological Survey Open-File Report 84-805, 28 p.

1985, Test wells T27 and T28, White Sands Missile Range, Doña Ana County, New Mexico: U.S. Geological Survey Open-File Report 84-809, 19 p.

1987, Test wells TW1, TW2, and TW3, White Sands Missile Range, 0tero County, New Mexico: U.S. Geological Survey Open-File Report 87-47, 19 p.

Orr, B.R., and Myers, R.G., 1986, Water resources in basin-fill deposits in the Tularosa Basin, New Mexico: U.S. Geological Survey Water-Resources Investigations Report 85-4219, 94 p.

U.S. Army Corps of Engineers, 1986, Ground based free electron lasertechnology integration experiment, Preliminary water supply investigations, White Sands Missile Range, New Mexico: Fort Worth, Texas, U.S. Army Corps of Engineers District, $28 \mathrm{p}$.

1987, Non-potable water supply well NP-1, Ground based free electron laser technology integrated experiment, White Sands Missile Range, New Mexico: Fort Worth, Texas, U.S. Army Corps of Engineers District, Completion and Evaluation Report, 38 p. 